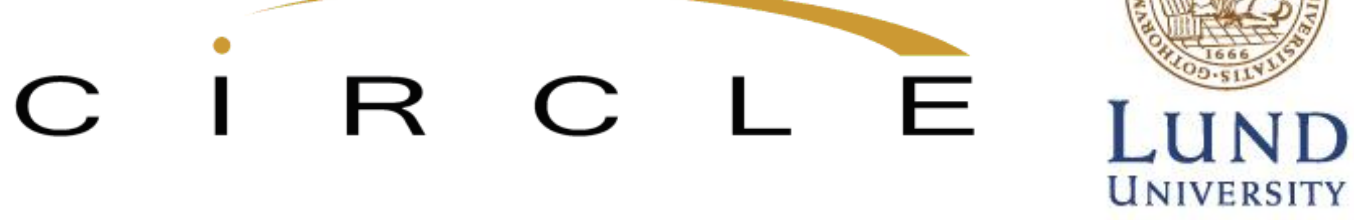

Paper no. 2011/03

\title{
Organizational paths of commercializing patented inventions: The effects of transaction costs, firm capabilities, and collaborative ties
}

\author{
Taehyun Jung (Taehyun.jung@ circle.lu.se) \\ CIRCLE, Lund University, Sweden \\ John P.Walsh (jpwalsh@gatech.edu) \\ School of Public Policy, Georgia Institute of Technology, USA
}

This is a pre-print version of a paper that has been submitted for publication to a journal

This version: April 2011

Centre for Innovation, Research and Competence in the Learning Economy (CIRCLE) Lund University

P.O. Box 117, Sölvegatan 16, S-221 00 Lund, SWEDEN

http://www.circle.lu.se/publications 
WP 2011/03

Organizational paths of commercializing patented inventions:

The effects of transaction costs, firm capabilities, and collaborative ties

Taehyun Jung and John P. Walsh

\section{ABSTRACT}

This study examines the factors affecting modes of commercializing patented inventions using a novel dataset based on a survey of U.S. inventors. We find that technological uncertainty and possessing complementary assets raise the propensity for internal commercialization. We find that $R \& D$ collaboration with firms in a horizontal relationship is likely to increase the propensity to license the invention. In addition, the paper shows that macro-level environment conditions that affect exchange conditions, such as technology familiarity, influence the effects of capabilities on governance choice.

Keywords: transaction cost economics; knowledge-based view; collaboration ties; commercialization; innovation; patent

Disclaimer: All the opinions expressed in this paper are the responsibility of the individual author or authors and do not necessarily represent the views of other CIRCLE researchers. 


\title{
Organizational paths of commercializing patented inventions: The effects of transaction costs, firm capabilities, and collaborative ties
}

\author{
Taehyun Jung ${ }^{\mathrm{a}^{*}}$ \\ a) Center for Innovation, Research and Competence in the Learning Economy, Lund University \\ P.O. Box 117, SE-221 00 Lund, Sweden \\ Email: Taehyun.jung@gmail.com \\ Phone: + 46-46-222 3191 \\ Mobile: +46-70-204 6665 \\ * Corresponding author \\ John P. Walsh ${ }^{\mathrm{b}}$ \\ b) School of Public Policy, Georgia Institute of Technology \\ 685 Cherry Street, Atlanta, GA 30332-0345 USA \\ Tel: 404-385-0400 \\ Fax: 404-385-0504 \\ Email:jpwalsh@gatech.edu
}

March 17, 2011

\begin{abstract}
This study examines the factors affecting modes of commercializing patented inventions using a novel dataset based on a survey of U.S. inventors. We find that technological uncertainty and possessing complementary assets raise the propensity for internal commercialization. We find that R\&D collaboration with firms in a horizontal relationship is likely to increase the propensity to license the
\end{abstract}


invention. In addition, the paper shows that macro-level environment conditions that affect exchange conditions, such as technology familiarity, influence the effects of capabilities on governance choice.

Keywords: transaction cost economics; knowledge-based view; collaboration ties; commercialization; innovation; patent

Acknowledgements: We would like to thank Japan’s Research Institute for Economics, Trade and Industry and the U.S. National Science Foundation (NSF0823372) for funding for this project. The Fraunhofer Institute for Systems and Innovation Research also supported part of the data collection for this study. In addition, the International Center for Economic Research and University of Torino and the Institute of Innovation Research at Hitotsubashi University supported Walsh while completing the work on this paper. We also thank Marco Ceccagnoli, Diana Hicks, Sadao Nagaoka, and Aldo Geuna for their helpful comments. Previous versions of this paper were presented at the Academy of Management meetings in Montreal, Canada, the DRUID conference in London, and Organization Science Summer Seminar in Bergen, Norway. 


\section{Introduction}

A great deal of attention has been given to the determinants of governance structure. The most important theoretical achievement has been probably made by transaction costs economists (Williamson, 2002). However, although TCE has proven to have strong predictive power on governance choice, it alone does not provide a comprehensive explanation about governance choice. While TCE focuses on the risk of ex post haggling and monitoring costs accompanying exchange, it overlooks the roles of transactional value (Zajac and Olsen, 1993), heterogeneous firm capabilities and production efficiency (Conner and Prahalad, 1996; Holmstrom and Roberts, 1998; Jacobides and Winter, 2005; Kogut and Zander, 1992), and inter-firm relationships (Poppo and Zenger, 2002). Even Williamson himself admitted some of these weaknesses in TCE as shown in the following statement: "the roles of organizational knowledge and learning ... are ones with which transaction cost economics deals with in only a limited way” (Williamson, 2002). This paper responds to this call by providing synthetic arguments that interweave the recent developments in TCE, capability-based views, and inter-firm ties and empirically testing these arguments using project-level data on invention characteristics and the commercialization decision for a broad sample of patented inventions.

In the context of firm innovation, TCE argues that firms tend to internalize innovation as the appropriability hazard (Oxley, 1997, 1999) of market transactions increases. One key policy instrument for reducing the appropriability hazard in transacting patented inventions is to strengthen patent protection. In addition, Teece (1986) argues that the rent from innovation accrues to the holder of difficult-to-reproduce complementary assets such as manufacturing, sales, and/or distribution capability. Following Teece’s argument, a firm having complementary assets is likely to use internal over external exploitation of the invention. In addition, recent work on innovation has emphasized the importance of inter-firm ties as a key driver of innovation performance, at both the firm dyad and whole network levels (Owen-Smith and Powell, 2004; Uzzi and Spiro, 2005). The literature about embedded ties (Powell et al., 1996; Uzzi, 1997) and exploration-exploitation (March, 1991; Rothaermel and Deeds, 2004) suggests that 
inter-organizational ties can be both important conduits for information flows, and can be alternative governance structures that may reduce opportunism and facilitate commercialization across firm boundaries.

In this study, we build on and further these existing theories (TCE, firm capabilities and interfirm ties) in the context of commercializing patented inventions. We start with the observation that technological innovation comprises invention and commercialization, two areas that require different capabilities (Afuah, 2003; Roberts, 1988; Schumpeter, 1942). Given an invention, the inventor or owner can choose different commercialization strategies. One of them is to integrate the invention into internal production capabilities (in-house commercialization) and another is to seek external paths across firm boundaries. The most prominent external commercialization path is to license out the invention to others. The use of external paths of commercialization have important implications for firms' competitiveness and the economy as a whole (Arora et al., 2001).

Using a data set constructed from multiple information sources, including patent documents, a large-scale inventor survey, and financial information on firms, we find that technological uncertainty and possessing complementary assets raise the propensity for internal commercialization. R\&D collaboration with firms in a horizontal relationship is likely to increase the propensity to choose external paths. In addition, we examine how technology uncertainty moderates the effects of firm production capabilities on the likelihood of internal commercialization. We also show that horizontal ties might moderate the negative effects of high technology uncertainty on the rates of technology licensing, showing support for the conjecture that such ties may provide alternative governance mechanisms that reduce transaction costs. We review the literature and develop our hypotheses in the next section. After describing the data and measures we report the results and conclude with a discussion of the findings and their implications.

\section{Theory and Hypotheses}

When a firm considers whether it will take an in-house development path or alternative options such as collecting royalties by licensing to other firms or establishing a spin-off firm and taking equities 
(we call these alternative options “external commercialization” throughout the paper) for commercializing a technology, it will assess the relative appropriability between them. Certainly, the relative appropriability of internal to external commercialization must depend on many particulars of a given technology and strategic interactions among firms. However, besides those particulars, we argue in this paper that some general attributes of a given invention as characterized by the evolutionary stage of technology field or by its linkage to the firm's production capabilities should affect a firm's decision about the commercialization paths. We reason how the evolutionary stage of technology field affects the commercialization paths in the next section and the effect of a linkage between an invention and production capabilities in the following section. In the final section, we discuss the effects of inventive inter-organizational ties on the governance choice of commercializing inventions.

\subsection{Technology Familiarity}

There are important differences between a mature and an emerging technological field, related to the nature of innovation, general level of cognitive difficulties in understanding and evaluating a new technology, and the availability of complementary technologies. Below we show how these characteristics affect the exchange conditions of commercializing inventions and result in different governance choices. To do so, we first discuss the characteristics of evolutionary stages of technology and then the reasons for their effects on the exchange conditions and governance choice.

As the first step we dichotomize the general characteristics of technology between emerging and mature fields. According to Dosi (1982), a technology field gets mature as a paradigm-setting technology emerges. Then, the paradigmatic technology sets a standard in both technological (e.g. how to recognize and solve technological problems) and socioeconomic dimensions (e.g. how to use the technology). Once the paradigm is set in a field then it will be populated with similar technologies following the same technology trajectory. As a result, a technology field that has reached a paradigmatic stage will show the following characteristics: 1) the field will be populated with a large number of similar technologies; 2) most technologies in the field will address minor technological issues and, therefore, be incremental; 3) because of this popularity and incremental nature, the utility and uses of a technology in the field will be 
evaluated with relative ease and accuracy by people working in the field; and finally 4) complementary technologies and assets required for using a technology will have been well established. Despite some differences in nuance and language, the linkage between the evolutionary stage of technology and its characteristics is generally supported in the literature (Abernathy and Clark, 1985; Anderson and Tushman, 1990; Tushman and Anderson, 1986; Utterback, 1994). Fleming (2001) and Fleming and Sorenson (2001) show that the variability in the utility of technologies decreases with the increase in the size of the recombinant search space of technological components. To summarize, we deduce that a technology field populated with more inventions on the same trajectory will be likely to be more familiar to people working in the field (and familiar to more people). Hence, inventions in such a field will be subject to a lower level of uncertainty, both technological and commercial, and enjoy a broader and faster availability of complementary technologies.

An invention from a familiar technology area, characterized by low technological uncertainty and readily available complementary technology, will be more likely than an invention from a less developed technology area to be externally commercialized for two reasons. First, the costs for negotiation rise as uncertainty increases. When potential applications of a technology are not clearly known at the time of contracting, a buyer would worry about overpaying for that technology while the owner would worry about underestimation of the value. Moreover, appraising the future value of the technology will also incur additional costs of information processing or of building a proper level of capacity (Cohen and Levinthal, 1990). Therefore, uncertainty deters market transactions for such a technology. As for asset specificity, suppose an invention in a new field, which has not been integrated into an industry's products. Then, commercializing this invention would require manufacturing and marketing capability specific to the invention, and it is most likely that these complementary assets could be developed by those most knowledgeable about that technology: the inventor or the inventor's organization (therefore favoring internal commercialization). Also, as TCE generally predicts, high asset specificity will increase the hazard of opportunistic behavior and suppress external sourcing of such capabilities (making external commercialization risky). In sum, an invention composed of more familiar technological components will 
ease identification of the potential utility and commercial applications and benefit from a larger amount of complementary technologies needed for commercialization (possibly from multiple vendors). These arguments suggest the following hypothesis.

H1: A patented invention belonging to a more familiar field of technology will be less likely to be internally commercialized.

\subsection{Complementary Capabilities}

In the markets for innovative products, possession of, or time to build, complementary capabilities is critical for performance and survival of a firm (Mitchell, 1991). Teece (1986) argues that, in sourcing complementary assets, an innovator would choose the better strategy between integration (internal commercialization) and contract (external commercialization) conditioned on how the complementary assets are structured within or across firm boundary and how well the innovator is positioned in the given asset structure. For example, in the cable connector and specialty cable manufacturing industry, Argyres (1996) found that capabilities differentials between the manufacturer and suppliers influenced the manufacturer’s outsourcing decisions. Similarly, Leiblein and Miller (2003) found that the fabrication experience of integrated circuit manufacturers raised the propensity of vertical integration and sourcing experience raised the propensity of outsourcing. Arora and Ceccagnoli (2006) found evidence that the higher the inter-functional communication frequency within a firm, which they regarded as difficult-to-imitate specialized assets, the lower the incentives of firms to respond to the licensing prospects for the patented innovations. We build on this line of literature to explore how the existing production capabilities of a firm affect the firm's decision regarding the integration of novel technology into its production and process.

We argue that firms integrate, rather than outsource, the production components that are closely

linked to their existing capabilities based on both capability-based views and transaction costs. Consistent with the capability-based logics, by integrating new technological components closely linked to the existing production capabilities a firm can readily deploy the existing skills to commercializing the new components and, hence, enhance skills-related production efficiency (Tushman and Anderson, 1986). It 
can also utilize existing manufacturing facilities with minimal modification to accommodate the new technology, thereby enhancing scale-related production efficiency (Poppo and Zenger, 1998). Firms will have a higher incentive to internalize the technologies closely related to their existing production capabilities because learning opportunities (Kogut and Zander, 1992; Leiblein and Miller, 2003) and the prospect of internal synergy (Conner and Prahalad, 1996) accompanying the internalization process are more likely to materialize in their production process.

Turning our eyes from the production side to the exchange side, we reach the same prediction. New technological components closely linked to a firm’s existing production capabilities are likely to have more 'firm-specific' elements. Exchanging these components in markets is harder than exchanging more generic components because transferring 'firm-specific' technology to external organizations incurs additional costs to the exchange partners (Argyres, 1996). For example, the technology receiver needs to expend more effort to assimilate the possible tacit elements originating from the technology creator's production capabilities while the creator may be reluctant to transfer such tacit elements for fear of risking its existing competence in production systems. In addition to firm specificity, proximity of a technology to a creating firm's existing production capabilities indicates that the firm may have an advantageous position in commanding the complementary assets that are required for utilizing the technology. This raises the barrier for market exchange of the technology because a potential receiver (or licensee) may fear possible ex post haggling by the creator (or licensor) based on its advantageous asset position. Additionally, leveraging its advantageous asset position as a bargaining power (Arora and Ceccagnoli, 2006) the licensor may impose a more favorable licensing conditions which inject additional frictions in the licensing deal. The above arguments suggest the following testable hypothesis regarding commercialization of patented inventions.

H2a: A patented invention more strongly coupled with the firm's existing production capabilities will be more likely to be internally commercialized.

Both arguments above predict the effects of firm capabilities on integration in a consistent way but from different angles - related to production efficiency for capability-based reasoning and exchange 
conditions for TCE. However, there are few studies that have examined the effects of capabilities on integration independently from the exchange conditions. This might be ascribed to the fundamental confound between production efficiency originated from capabilities with exchange conditions. Indeed, some capability theorists argue that the current firm-specific capabilities are the result of the past boundary decision influenced by exchange conditions (Argyres and Zenger, 2008; Poppo and Zenger, 1998) and that they co-evolved with the exchange conditions (Jacobides and Winter, 2005). Here, we will argue that the effects of capabilities on boundary choice are conditioned on technology familiarity, which affects the exchange conditions. Technological innovations have the asset values (Tushman and Anderson, 1986) which will be differently evaluated by firms conditioned on not only their internal utility and fitness but also availability of comparative external options. There are competing arguments in the literature regarding this aspect. Zelner (2009) found that the higher demand uncertainty, the higher the positive impact of asset specificity on vertical integration. For example, imagine an extreme case such that an invention belongs to a very familiar technology area and, hence, technological uncertainty is low. In this case, even if an invention contains firm-specific elements in it, it would not raise the transaction costs as much as it does for a less familiar technology because buyers of the technology will know more about the technology. Therefore, the additional transaction costs and bargaining power stemming from firm specificity will have a relatively smaller impact on the boundary decision. Moreover, internal learning opportunities from the familiar technology will be smaller than from an unfamiliar technology, which reduces incentives for integration of familiar technology even if it is closely linked to existing capabilities. On the other hand, the impacts of skills-related or scale-related production efficiency on boundary decisions will be invariant over changes in uncertainty condition. Here, both TCE and capabilities arguments again predict in the same direction, which we formulate as the following hypothesis.

H2b: The more familiar the technology environment, the smaller the impact of an invention's coupling with existing firm capabilities on the propensity of internal commercialization. 


\subsection{Inter-organizational ties}

Inter-organizational ties are important conduits for information flows (related to both market and technological opportunities), as well as vehicles for creating trust, which may affect the relative benefits and costs of external versus internal commercialization. In this paper, we will focus on a particular interorganizational tie, collaboration during the R\&D process (or inventive collaboration), and then show its impact on the governance choice for commercialization. We start by discussing how inventive collaboration forms embedded ties, then draw from the literature their key characteristics relevant to governance choice, and argue how these characteristics affect governance choice.

Inventions are usually an outcome of combining diverse problem-solving capabilities and, thus, often benefit from information sharing among people having expertise in various technologies and instruments (Arthur, 2007). When a firm lacks some of these capabilities, it sources them from outside. Because those capabilities usually include tacit and firm-specific elements (Nelson and Winter, 1982; Powell, 1990), transferring them from one entity to another requires repeated interactions and communications, which results in collaboration, either formal or informal. Through the repeated joint problem-solving and information sharing activities, collaboration partners naturally build up trust and relational inertia which turn into embedded ties (McEvily and Marcus, 2005). Inter-firm embedded ties formed as such influence future economic exchanges (Granovetter, 1985; Powell, 1990; Uzzi, 1996) and, thanks to greater trust and shared information among tie partners, reduce the risks of opportunism and the costs of negotiations between the tie partners (Jones et al., 1997b; Uzzi, 1997; Zaheer et al., 1998).

Drawing from the literature, we identify three key elements of inter-firm embedded ties that may affect the governance choice of a tie partner: relational inertia, knowledge (especially about capabilities) and trust. To begin, we expect that routines and relationships built up during the invention collaboration are likely to persist into the commercialization phase of the project. Once the investment in an interorganizational tie has been made, firms are likely to continue to work with the same partner unless there is strong reason to change. In other words, there is significant inertia in inter-organizational relationships (Stinchcombe, 1990). For example, empirical studies about alliance and organizational learning suggest 
that ties formed during the explorative stage of innovation are likely to be maintained in exploitative stage (Powell et al., 1996; Rothaermel and Deeds, 2004).

Inter-firm ties are also an important channel for knowledge transfer in innovative activities (Afuah, 2000; Mowery et al., 1996; Owen-Smith and Powell, 2004; Powell et al., 1996; von Hippel, 1988). Benefits from participating in the knowledge exchange ties are multifold to the participants. First of all, they can acquire particular problem-solving know-how. In addition, through access to a larger pool of technological elements provided by tie partners, they can see and grasp technological opportunities in a more timely and accurate manner (Fleming, 2001; Katila and Ahuja, 2002). Exchange of either problemsolving know-how or technological opportunities, then, enhances the overall quality of inventions and strengthens the absorptive capacity of tie participants (Cohen and Levinthal, 1990). Knowledge transferred over inter-firm ties also includes market and demand opportunities (Achrol, 1997; Podolny and Page, 1998; Stuart et al., 1999). Through exchange of knowledge about market and demand, tie partners can better understand and evaluate the market potential of a technology and may discover unforeseen opportunities attached to the technology. Finally, knowledge exchanged between collaborators during the invention process may include fine-grained information on partner (or even third party) capabilities and commercialization strategies, which may be key for developing licensing opportunities for commercializing the technology. For example, during technology development, the focal firm may be concentrating on one application, for which it has in-house capabilities, but learn that its partner (or another firm) has an idea for a high-value use that requires different capabilities that the focal firm does not possess, but the other firm does, suggesting the opportunity to license the technology for greater return.

The effects of inter-firm ties on governance choice are likely to differ depending on whether the collaboration with a partner along the value chain, such as suppliers or customers (or vertical collaboration), versus collaboration with partners across the value chain, such as competitors or firms in the same industry (or horizontal collaboration). For example, production capabilities and resources are likely to be more complementary and mutually dependent between firms in a vertical relationship than in 
a horizontal relationship (Galaskiewicz, 1985). Accordingly, knowledge transferred between firms in vertical collaboration is more likely than in a horizontal collaboration to have complementary, local, contextual, or product-specific elements (Dyer and Nobeoka, 2000; von Hippel, 1988) and to be targeted to commercial application (Cohen and Levinthal, 1989, 1990). Consequently, inventions developed through vertical collaboration will have incorporated more product-specific and firm-specific technological elements than inventions developed through horizontal collaboration. Thus, inventions developed through vertical collaboration will be more likely than through horizontal collaboration to be internally commercialized because of higher gains from learning opportunities, skills-related production efficiency, and the prospect of internal synergy on one hand, and, on the other hand, higher costs of transferring such technologies to the third party who has not joined the vertical collaboration.

In addition to inertia and knowledge exchange, inter-organizational collaboration during the invention stage should build trust between partners, which lowers the opportunism hazards, and therefore increases the propensity for external commercialization (see below). At the same time, inter-firm ties transfer knowledge and information in both directions between the focal firm and the tie partner. Thus, not only the focal firm but also the collaboration partner will have developed technological and market capabilities through collaboration, leading to spillovers and possibly a loss of lead time advantage for the focal firm. The partner may then be in a strong position to incorporate the invention (or closely related technologies) into its own innovation. This may or may not be a violation of the trust built up in the R\&D collaboration, depending on the nature of the spillovers. In fact, such sharing of the rents may have been part of the initial expectations of the collaboration. This scenario would also predict a high rate of outlicensing of inventions built on R\&D collaboration, either as a continuation of the relationship already developed (and hence, reinforcing the inertia and trust), or as a result of rent dissipation, leaving the focal firm with the second best option (after exclusive use) of licensing, perhaps broadly, to capture some returns from the invention. If this spillover and rent dissipation effect is strong, then we would likely find higher licensing for inventions growing out of horizontal collaborations. In addition, we may find these horizontal collaborations result in multiple licensees, suggesting that, in the face of spillovers that 
dissipate the rents from exclusivity, the focal firm is capitalizing on its invention by licensing broadly (Arora and Fosfuri, 2003; Arora et al., 2001).

Based on these arguments, we suggest that inter-organizational ties in the form of R\&D collaboration are likely to generate inertia, information flows and trust that will increase the rates of external commercialization. Furthermore, the rent dissipation argument tied to spillovers also suggests that licensing should be higher for horizontal collaborations. On the other hand, for vertical collaborations, because of the countervailing effects of the ability to exploit complementary capabilities and the lower likelihood of rent dissipation, we do not have a clear prediction on the net effect on internal versus external collaboration. Therefore, we will focus on the following testable hypothesis.

H3: A patented invention developed through collaboration with firms in horizontal relationships will be more likely to be externally commercialized than inventions developed without such collaboration.

\subsection{Embeddedness, Uncertainty and External Commercialization}

In addition to the direct effects of trust on increased licensing mentioned above, prior work also suggests that inter-organizational ties may be important for reducing the risk of opportunism in transactions (Granovetter, 1985; Powell, 1990; Uzzi, 1997). Following Granovetter (1985), Stinchcombe (1990) and Uzzi (1997), we will focus on the embeddedness of dyadic ties that comes from ongoing interactions, and is associated with fine grained information transfer, joint problem solving, and development of trust. In addition to dyadic embeddedness, prior work has also highlighted the importance of structural embeddedness as an additional mechanism that may reduce the risks of opportunism due to the existence of shared alters that can sanction malfeasance (Coleman, 1988; Jones et al., 1997b). While structural embeddedness is also potentially important, in the context of inter-firm ties, especially R\&D collaboration and licensing of inventions (both of which often involve secrecy), dyadic relationships are likely to dominate, and we will focus on this meaning of embedded tie.

Prior work suggests that embedded ties can serve as alternative governance mechanisms in between markets and hierarchies (Powell, 1990; Uzzi, 1997). In the context of innovation, we argue that successful R\&D cooperation is likely to result in an embedded relationship, such that the two firms 
involved begin to develop greater trust, greater orientation to join problem solving, and expectations of future relationships that get incorporated into the decision making process. This embeddedness should lead to reduced fears of opportunism by the partners, and can provide a supplemental governance structure that can help overcome some of the limitation to contracting in the face of high uncertainty and a dependence on relation-specific assets under the control of the partner (Uzzi, 1997; Williamson, 1985). Inter-organizational trust is, as defined by Dyer and Chu (2000), “one party's confidence that the other party in the exchange relationship will not exploit its vulnerabilities.” Thus, while high technological uncertainty is likely to dampen licensing as discussed above, this effect is likely to be mitigated if the partners have a strong prior relationship, such as a successful joint R\&D project, suggesting the following hypothesis:

H4: The more unfamiliar the technology, the stronger the positive effects of horizontal collaboration on external commercialization.

\section{Data and Measures}

\subsection{Data}

In order to test these hypotheses, we constructed a novel data set from multiple sources: an inventor survey, the United States Patent and Trademark Office online database, the European Patent Office Worldwide Patent Statistical Database (henceforth, PATSTAT), and COMPUSTAT for firm financial information. The 'U.S. Inventor Survey 2007’ was conducted in the summer of 2007. The population for the survey is the of OECD triadic patent families ${ }^{1}$ compiled and provided by the OECD in January 2007 (OECD, 2006). We use triadic patents as our sampling frame to facilitate survey administration $^{2}$ and enhance cross-national comparability. In addition, by focusing on triadicly patented inventions, we have a greater chance of having commercialized inventions in our sample (since filing in

\footnotetext{
${ }^{1}$ Triadic patents are equivalent patents granted in the USPTO and filed in both the European Patent Office and the Japan Patent Office.

${ }^{2}$ By using triadic patents, we could retrieve the home address of U.S. inventors from the EPO database.
} 
three jurisdictions acts as a threshold screen that eliminates many low value patents). Since our focus is on the mode of commercialization, this lets us concentrate our data collection effort on inventions that are more likely to be commercialized at all.

The OECD triadic patent database identifies 84,021 triadic patent families whose priority patent was filed between year 2000 and 2003, inclusive. Our population is the 32,390 triadic patent families that had at least one inventor with a U.S. address. Because some patent families are associated with multiple U.S. patents, our population includes 74,705 different U.S. patents. For comparison, about $40 \%$ of priority year 2000 U.S. patents were also triadic patents. We drew a systematic sample of 9,060 triadic patent families with at least one U.S.-addressed inventor, stratified by NBER technology class. Taking the first available US inventor from the first granted U.S. patent in each family as the representative inventor, and after randomly drawing one patent for inventors with multiple patents in our sample, we have 7933 unique U.S.-based inventors in our mail-out sample. To identify duplicate inventors, we used name and home address. For the small number of inventors having the same name but different home addresses, we examined identified individuals by using their assignee and co-inventors (see Lai et al., 2009). After sending the survey packet (with first-class stamps and individualized, signed cover letters), follow-up letters and a second-wave mailing of the full packet, we received 1919 responses (24.2\%). After excluding undeliverables, deceased, etc., from the denominator, we have an adjusted response rate of 31.8\%. We excluded 113 patents not associated with firms (including, but not limited to, independent inventors and university patents), based on a survey question asking about the organization to which an inventor belonged at the time of invention. For the small number of patents missing on this question, we sorted out non-firm patents by looking at assignee fields. After further removing 580 observations missing on our variables, we are left with 1226 patents associated with firms, including both public and private firms, large and small firms, and inventions from across the USPTO technology sectors. For our main analyses, we limit the sample to the 651 commercially used patents.

While large firms may be better positioned to file globally, a detailed comparison of the firms in our sample shows that the firm size distribution in our sample is not significantly different from the 
underlying population of innovating firms (Jung, 2009). In particular, there are a substantial number of small and medium firms in our sample (about $18 \%$ of the sample of patents come from firms with less than 500 employees). However, we should note that not all inventions are patented, and that patent propensities vary by industry, so that we should be careful when making inferences from this population of inventions (Cohen et al., 2000). Still, this population represents a significant subset of inventions, and is likely to especially represent those inventions with a high-risk for global commercialization (cf. Gambardella et al., 2008; Harhoff et al., 1999). Also, patenting is often considered a pre-condition for licensing of technology (although this is not always the case and software is a major exception). Thus, if we are interested in the choice between in-house use and licensing, limiting our sample to patented inventions may help increase the comparability of the inventions in the two choices. ${ }^{3}$

In order to test for response bias, we conducted a series of unequal variance t-tests for the mean values of some key patent indicators between the analysis sample $(n=1226)$ and the rest of the survey population (N=9060-1226). We did not find significant differences between the two groups. In particular, measures of collaboration (solo inventions: $26.3 \%$ for the analysis sample, $26.8 \%$ for the rest, $\mathrm{p}=0.69$; average number of inventors: 2.80 for the analysis sample, 2.74 for the rest, $\mathrm{p}=0.34$ ), the technological breadth of invention (the number of different US Patent Classes: 4.44 for the analysis sample, 4.61 for the rest, $\mathrm{p}=0.14$; the number of different International Patent Classes: 4.77 for the analysis sample, 4.85 for the rest, $\mathrm{p}=0.44$ ), the scope of invention (the number of claims: 3.44 for the analysis sample, 3.59 for the rest, $\mathrm{p}=0.06$ ) and measures of patent value (Log(forward citations), 0.97 for the analysis sample, 0.99 for the rest, $\mathrm{p}=0.43$ ) are all similar (none are significantly different at $\mathrm{p}<0.05, \mathrm{~N}=9060$ ). ${ }^{4}$ In conclusion,

\footnotetext{
${ }^{3}$ Of course, patenting is partially endogenous to the expected mode of commercialization, so this is one limitation of this sample.

${ }^{4}$ We found statistically significant differences for only two variables, which we do not see as significantly affecting the sample. The analysis sample includes a somewhat smaller number of patents for which we only had a company address, instead of the home address (4.2\% of the analysis sample had only a company address v. $5.8 \%$ for the rest,
} 
despite the modest response rate, we have some confidence that our sample is representative of the underlying population of US-based triadic patents.

\subsection{Variables and Measures}

\subsubsection{Dependent Variable—Modes of Commercialization}

The U.S. Inventor Survey 2007 asks inventors about commercial use and the reasons for nonuse of their patented inventions. We identify a patented invention as commercially exploited if it is 1) commercialized in a product/process/service by the applicant or owner of the patent, 2) licensed out or put in a cross-license deal by (one of) the patent-holder(s) to an independent party, or 3) commercially exploited by the respondent or any co-inventor for starting a new company. Out of 1,226 complete cases, 651 (53.1\%) patents were reported as being commercialized. The dependent variable Internal commercialization is coded 1 for those observations reporting that a patent is "commercialized in a product/process/service by the applicant or owner of the patent” but not licensed (including cross-license) nor commercially exploited by the respondent or any co-inventor for starting a new company. Note that the sample is limited to the responses in which the respondent belonged to firms at the time of invention. This limiting condition removes university start-ups from the sample. Among the patents in commercial use, 74\% were used purely internally. The rest of the commercialized patents are regarded as "external commercialization.” Out of 169 patents thus identified as “external commercialization,” 113 patents were also used internally. We classify these dual-use patents as “external use” for two reasons. First, it is possible that some respondents misinterpreted the internal use question and answered "yes” if the company's use of the invention was to license it (an overly broad understanding of internal use). Second,

$\mathrm{p}<.01$ ). The linkage to universities or science is also somewhat lower in our sample than the survey population as indicated by lower mean of the number of “Non-patent References” in the patents, which often includes references to scientific publications (4.07 for the analysis sample, 4.96 for the rest, $\mathrm{p}<0.05$ ). We would expect that the university linkage of our analysis sample should be somewhat lower because we removed from our analysis sample all university patents (which likely have higher cites to non-patent literature). 
these dual-use inventions, which likely share some traits with internal use and other traits with external use, would blur the distinctions between the two modes and thereby produce conservative tests of our predictions about the differences between internal and external use. We discuss the different specifications of the dependent variable in more detail below.

\subsubsection{Explanatory Variables}

We operationalize technological familiarity using a familiarity index of technological components based on Fleming (2001). The component familiarity index captures the degree to which a patentee is familiar with the technological components that were used in his patent. As a technology matures (and, therefore, the population of technological artifacts increases), technological trajectories based on this technology become more foreseeable and less uncertain (Dosi, 1982). The individual component familiarity for patent $i$ is calculated as follows,

Component familiarity for patent $i=$

$$
\frac{1}{N_{C_{i}}} \sum_{c_{j} \in C_{i}} \sum_{\begin{array}{l}
\text { all granted patents } k \\
\text { filed from } 1976 \text { to } 1999
\end{array}} 1\left\{\text { patent } k \text { assigned to subclass } c_{j}\right\} \times \text { kattenuation }_{k}
$$

where $C_{i}=, C_{j}=$ patent subclass identifier, and $N_{C_{i}}=$ number of different patent subclasses assigned to patent $i$. We depreciate old knowledge by applying a knowledge attenuation factor kattenuation $_{k}=\operatorname{Exp}_{\text {[- }}$ (temporal distance of patent $k$ / time constant of knowledge loss)] where temporal distance of patent $k$ is set to 4.5 if patent $k$ was filed from 1995 to 1999; 9.5 if it was filed from 1990 to 1994; and 18.5 if it was filed from 1976 to 1989 . The temporal distance is calculated by subtracting the median issue year of patents over the given period from the median filing year of the focal patent in our sample (=2001.5). The time constant of knowledge loss is set to 5 years, following Fleming (2001). We rescaled component familiarity by dividing it by 1000 .

We measure the strength of the link between a patented invention and the firm's existing production capabilities using two survey measures: 1) whether an inventor belonged to the manufacturing unit and 2) whether the goal of the invention was to create a new product or process ("new-to-the-firm invention”) or to improve existing products or processes. An inventor belonging to the manufacturing unit 
is assumed to be more knowledgeable about the firms' manufacturing processes and capabilities, to maintain stronger ties with technicians working on manufacturing lines, and to be more able to couple the invention with the internally available co-specialized assets. The variable Manufacturing unit is coded 1 if the inventor belongs to the manufacturing unit and 0 for the R\&D unit, software development, sales $\&$ marketing, or others. The second measure, Improvement, was coded 1 if the innovation was to improve an existing process or product and 0 if the innovation was to create a new process or product. Here, we are assuming that new-to-the-firm inventions are more detached from the existing capabilities than are improvement inventions, which are likely to be closely linked to existing capabilities (Tushman and Anderson, 1986).

Finally, we measure inter-firm ties by using collaboration during the invention process. While this is only one form of inter-organizational tie, this measure captures an important dimension of knowledge sharing and trust between firms (since cooperating during the R\&D stage of innovation often requires sharing important technical and strategic information). We measure invention collaboration using the questions asking about presence of external co-inventors or collaborators. The survey asked respondents to report how many inventors came from the respondents own firm and how many came from any of the following types of external organizations: suppliers, customers and product users, competitors, non-competitors within the same industry, other firms, universities, government research organizations, hospitals, and other. We also asked respondents if, during the research process that led to the patented invention, their firm had any formal or informal collaborations with other organizations (excluding coinventors). We take the union of these two measures as our measure of inter-organizational R\&D collaboration. The binary variable Horizontal collaboration is coded 1 for co-invention or collaboration with competitors, non-competitors within the same industry, or other firms. We also control for collaboration with firms in a vertical relationship or with public organizations by including the variables, Vertical collaboration, which is coded 1 for co-invention or collaboration with suppliers or customers and 0 otherwise, and Public collaboration, which is coded 1 for co-invention or collaboration with universities, government research organizations, or hospitals and 0 otherwise. About $31 \%$ of horizontal 
collaboration is with competitors and about $68 \%$ of vertical collaboration with suppliers. This grouping of collaboration types into horizontal, vertical and public reflects the latent factor structure as based on an exploratory factor analysis using tetrachoric correlations, as well as our theoretical priors about the distinctiveness of vertical versus horizontal collaborations (discussed above).

\subsubsection{Controls}

We control for two firm-level factors: firm size and firm patent stock. Size is known to be an important factor determining a firm’s propensity to license (Gambardella et al., 2007). Using the survey and complementary data sources such as COMPUSTAT, the Patent Fee Maintenance Database of the USPTO, and company websites, we coded the variable Large firm as 1 if the inventor belonged to a large firm (defined as having more than 500 employees) at the time of invention and 0 otherwise. As a check on the reliability of our survey responses, we find a 92\% agreement between the self-reported Large firm measure and the size data in COMPUSTAT, and an 86\% agreement between the self-reported Large firm measure and the USPTO small entity designation. The COMPUSTAT and USPTO measures have a 97\% rate of agreement, suggesting that these measures also have some measurement error. We control for the technological capabilities of firms using the logarithm of firm patent stock, Ln(patent stock), as a proxy. We define patent stock as the sum of U.S. patents granted to the first assignee of the focal patent. The patent stock of firm $i$ for a focal patent filed in year t is $\mathrm{PS}_{i t}=\mathrm{PS}_{i(t-1)}(1-\delta)$ where $\delta$ represents the knowledge depreciation constant, which is set to 15\%, following previous studies (Grimpe and Hussinger, 2008; Hall, 1990). We collected the data from the PATSTAT database (April 2008 version) and consolidated the patent stock of subsidiary firms into the count of their ultimate parents and that of merged and acquired firms into the mergers.

In addition to firm-level controls, we control for many invention and patent level factors that are likely to affect the probability of licensing versus in-house use. At the invention level, we control for the importance of various external knowledge sources. The U.S. Inventor Survey 2007 asks how important various knowledge sources were for: 1) suggesting the project and 2) contributing to the completion of the project (two items). The measure is a 6-point scale with 0 for “did not use," 1 for "not important," and 5 
for "very important.” For each source of knowledge we took the maximum value of the scores for the suggestion and completion questions and then constructed a normalized mean score. Industrial knowledge is the mean score on the following five knowledge sources: patent literature, fair or exhibition, standards documents, customers and product users, suppliers, and competitors (Cronbach's alpha=0.66). Public knowledge is the mean of the following four knowledge sources: scientific literature, technical conferences, universities, and government research organizations (Cronbach’s alpha=0.69). This grouping is also empirically reasonable as indicated by a confirmatory factor analysis (Chi-square pr.> 0.15; $\mathrm{NFI}=0.99 ; \mathrm{GFI}=1.00$ ). We also control for the project goal. The survey asked if the purpose of the research was "enhancing the technology base of the firm or the long-term cultivation of technology seeds" (in contrast to creating a new line of business or enhancing an existing business). The variable No immediate demand is coded 1 if the goal was to enhance the technology base and 0 otherwise. We also control for the proportion of the inventor's time spent on basic research (\% basic $R \& D)$, based on the survey response. The technological value of the invention (Technological value) is controlled using the inventor's self-assessment of the valuation following recent work on valuing patents (Gambardella et al., 2008). In our survey, we asked the inventor to assess the technical significance of her invention relative to other technical developments in her field during the year the focal patent was applied for. We code 4 for top $10 \%$, 3 for top $25 \%$ (but not top 10\%), 2 for top 50\% (but not top 25\%), and 1 for bottom half. We control the resources invested in the invention using two different measures. The variable man-months is an ordinal variable constructed from the survey question asking “[a]pproximately how many man-months did the research leading to the focal patent require?” The answer categories were: less than one manmonth; 1-3 man-months; 4-6; 7-12; 13-24; 25-48; 49-72; 73-96; and more than 97 man-months. The top category was set to 108.5. We then used normalized median values (dividing each group median by the top category median) as the measure of relative project size. We also control for the number of inventors, based on the U.S. patent publication. Because product and process innovation differ in the likelihood of licensing, as well as other important dimensions (Cohen et al., 2000), we asked if the invention is a product, process or mixed invention (with Product invention equal to 1 if it is product and 0 if it is 
process or mixed). We control for the breadth of the patent using two proxy measures: the number of different technology classes and the number of claims. The number of different technology classes (Complexity of technology) can be regarded as a measure of the strength of the patent (Gambardella et al., 2007), complexity of technology, or scope of invention (Nerkar and Shane, 2007). We used the U.S. Patent Class (USPC) as assigned and organized by the USPTO. We also use total number of claims as a second measure of patent breadth (Lanjouw and Schankerman, 2004). The mode of use may also be affected by how much time the firm has had to exploit the invention (either internally or externally). The variable Age of invention measures how many months have elapsed from invention filing to the time of the survey. We also control for technology area. We distinguish six different technology areas using the OST/INPI/ISI nomenclature (OECD, 1994). Descriptions and summary statistics for the variables are presented in Table 1. As shown in Table 1, about 74\% of commercialized inventions are used internally and that about $10 \%$ were by inventors in the manufacturing unit. We see that $43 \%$ of inventions were improvements to existing products or processes. Finally, we find that $7.5 \%$ of commercialized inventions involved horizontal collaboration, 27\% involved vertical collaboration and 7\% involved collaboration with public organizations.

$<$ Insert Table 1 here $>$

When we compare across technology areas, we find that the rate of internal commercialization is highest in mechanical engineering and machinery (with almost 90\% of commercialized inventions used in-house). In contrast, licensing is highest in chemicals and pharmaceuticals, with over $30 \%$ of commercialized inventions used externally (cf. Arora, et al., 2001). The rate of horizontal collaboration is highest in consumer goods \& construction (16\%), followed by mechanical engineering (10.4\%).

\section{Results}

We used probit regressions (internal versus external commercialization) to test the effects of technology familiarity, links to firm capabilities and inter-firm ties on the probability of in-house commercialization (Table 2). For these regression we restricted the sample to commercially used patents 
( $\mathrm{N}=651$ ). Model 1 is the baseline model, showing with only controls: importance of knowledge from firms and from public sources, being in a large firm, patent stock, patent value, no immediate demand, percent basic, product invention, project size, patent breadth, invention age and technology class. Models 2 and 3 include our explanatory variables, familiarity, ties to capabilities, and horizontal ties, with alternate measures of the invention's coupling with existing capabilities (improvement invention and manufacturing unit, respectively). In models 4 and 5 we add interaction terms between familiarity and our measures of links to capabilities, and between familiarity and horizontal inter-organizational ties. The right two columns in the table show the marginal effects of model 5 for a representative large firm and a representative small firm (with all other variables set to their mean or mode). All models are significant (p $<0.001$ ) with adjusted pseudo-R-squares ranging from 0.114 for the base model to 0.140 for Model 5. We discuss possible sources of bias of these specifications and present the results from alternative specifications later in this section.

$<$ Insert Table 2 here $>$

\subsection{Hypotheses Tests}

Our first hypothesis suggests that Component familiarity should be associated with more licensing (and hence lower rates of purely internal use). We find a negative and significant effect of familiarity on internal commercialization, suggesting that firms are more likely to license technologies as the technology domain becomes more populated with similar inventions. This effect is significant after controlling for knowledge spillovers from public sources, including patent literature. Thus, technological familiarity (and maturity of technology) has an impact on the commercialization process net of knowledge spillovers during the invention process. Even when we add the interaction effects, the effect of familiarity is consistently negative and generally significant $(\mathrm{p}<.10)$. In the model with the familiarity*improvement interaction term, the effect is not quite significant (model 4). We also find that inventions strongly coupled with the firm's existing capabilities are more likely to be internally commercialized, supporting H2a. For both measures, Manufacturing unit and Improvement, we find a significant positive effect, even in the model with interaction effects. Finally, we can see that Horizontal 
collaboration is associated with lower rates of internal use (higher licensing), consistent with H3. To help specify the mechanism that might drive the effects of horizontal collaboration, we checked to see if horizontal collaboration is associated with greater rent dissipation through spillovers. As argued above, if the $R \& D$ collaboration results in spillovers that reduce the focal firm's exclusivity, they may be more willing to license to multiple firms (because they have already suffered from a significant rent dissipation, and so can use the license to try to capture some returns to their investment). The survey asked, for those inventions that were licensed, how many different firms they licensed to. We compare the rate of multiple licensees between those who had a horizontal collaboration versus those that did not. We find that the rate of multiple licensees is higher (although not quite statistically significant at conventional levels) for those with a horizontal collaboration compared to other collaborations (44\% v. 23\%, Pearson chi2(1) $=2.24 \mathrm{P}<0.15)$, consistent with a spillover/rent dissipation explanation for external commercialization. However, since we do not know the number of collaborating firms, we cannot rule out that the number of partners differs between horizontal and other collaborations. We also see from the correlation table that there is a significant, but modest ( $\mathrm{r}=.10)$, correlation between horizontal collaboration and knowledge flows from firms. This result, combined with the fact that the effect of horizontal collaboration is significant net of knowledge flows, suggests that fine-grained information transfer may not be the main driver of the external commercialization effect. Thus, we have some evidence for spillovers/rent dissipation and for fine-grained information transfer as possible mechanisms. We could not test inertia or trust directly.

The last two columns in Table 2 give the effects sizes, both for a large firm and for a small firm (based on model 5 and setting the other variables to their mean or mode). As Component familiarity increases by 1 (or as there are about an additional 1000 knowledge-loss-depreciated patents in the same technology field as the invention) the probability of internal commercialization decreases by 17.3 percentage points for a patent from a large firm and by 23.5 percentage points for a patent from a small firm, holding other variables constant at their means or modes. The effects for links to firm capabilities are also substantial. A manufacturing unit invention has a 14.6 point higher probability of internal 
commercialization for large firms and a 25.2 point higher probability for small firms. Finally, horizontal collaboration lowers the probability of internal commercialization by 18.8 percentage points for a large firm and 21.2 percentage points for a small firm.

To test hypotheses $2 \mathrm{~b}$ and 4 , we added the interaction terms Component familiarity * Manufacturing unit in models 3 and 5, Component familiarity * Improvement in models 2 and 4, and Component familiarity * Horizontal collaboration in models 4 and 5. Although coefficients for the interaction terms are not significant, this does not tell us that there are no interaction effects. In a nonlinear model, the sign, magnitude, and significance of the coefficients on interaction terms vary with the covariates (Ai and Norton, 2003; Hoetker, 2007; Zelner, 2009). Thus, we examined the interaction effects conditional on the covariates using two different methods: 1) computational calculation, as suggested by Norton, Wang, and Ai (2004) and 2) simulation-based calculations developed by King et al. (Tomz et al., 2003). We obtained consistent results from both methods and, thus, report only the analysis from the latter. Figure 1 presents two plots: panel (a) shows the predicted probabilities for manufacturing unit (dashed line) and for non-manufacturing unit (solid line) inventions and panel (b) shows their difference (line) and 95\% confidence intervals (shade), which we computed from 651 sets of simulated coefficients from a multivariate normal distribution whose mean and variance are equal to the estimated coefficient vector and the estimated variance-covariance matrix, following Tomz et al. (2003) and Zelner (2009). All the probabilities and the interaction effects are calculated for a representative large firm, as we used above for calculating marginal effects in Table 2 (based on model 5). In order to more easily see the effects, we focus on the lower range for Component familiarity ( 0 to .25, which covers $95 \%$ of data points). Figure 1 gives the results for the interaction of familiarity and capabilities. As we expected, based on TCE, the effects of existing capabilities on internal commercialization decrease as technology familiarity increases (panel (a)). The difference in the predicted probabilities between high and low capabilities linkages (manufacturing inventions or not) is only significantly different from (and higher than) zero when technological familiarity is low, consistent with H2b. However, as indicated by overlapping shadows between the low (around 0.03) and the medium level (around 0.07) of Component 
familiarity, the difference is not significantly larger at lower familiarity than at higher familiarity.

Therefore, we can only say from our estimation that the impacts of existing capabilities on the commercialization mode choice tend to be highest when technological familiarity is low, but the effect is not continuous and for much of the range the effects appear not to be statistically significant, providing limited support to H2b.

We also hypothesized that the effects of uncertainty may be lower when the invention was based on horizontal ties. Figure 2 shows similar plots for the interaction Component familiarity * Horizontal collaboration. Horizontal collaboration is associated with a lower probability of internal commercialization (panel (a)). However, the gap seems to be narrower (rather than larger) when familiarity is low (in other words, in the range where TCE would predict licensing is difficult). When we look at panel (b), the predicted differences in probabilities are negative and statistically significant at lower levels of Component familiarity (below 0.16), and the gap increases (rather than decreases) as familiarity increases, although the standard errors also increase. Thus, we do not find evidence to support H4. Instead, we find some evidence that the effects of R\&D collaboration on commercialization mode are strongest when technology is familiar enough to support bargaining, at which point inter-firm ties can help reduce opportunism in technology contracting.

$<$ Insert Figure 1 here $>$
$<$ Insert Figure 2 here $>$

\subsection{Other effects}

Our estimates show strong and consistent results that patents from large firms are more likely to be internally commercialized. The coefficients on "large firm” are highly significant and positive across the models ( $\mathrm{p}<0.01$ ), consistent with findings from European data (Gambardella et al., 2007). Our measures of patent breadth (Number of claims and Complexity of technology) do not have a significant impact on commercialization mode, which is different from what Gambardella et al. (2007) found from the PatVal-EU survey. However, some of this difference may be due to differences across patent systems in claims writing and the assignment of patent classes to inventions. We find that when knowledge in the 
patent builds heavily on information from other firms, it is more likely to be used internally, while when it builds on public knowledge, it is more likely to be licensed, perhaps reflecting the tacit v. codified knowledge distinction. In contrast to Kim and Vonortas (2006), our estimation does not show a significant relationship between the patent stock of a firm and the propensity to commercialize externally (which includes licensing).

We found no significant impact of patent breadth on the governance choice of commercialization. This is probably because of multiple meaning attached to the measures. As Gambardella et al. claimed, as technological scope and complexity increase, the possibility of inventing-around will decrease; thus, the protective role of the patent will be strengthened (and therefore licensing should increase). This is one interpretation. Another interpretation is that the larger scope and the higher complexity the higher the transaction costs (and therefore licensing should decrease). These multiple connotations from the same measure work in the opposite directions with regard to the commercialization mode, which may explain the null result.

\subsection{Robustness Checks}

\subsubsection{Alternative specifications}

The tests above use a data set comprising commercially used patents. These specifications may result in biased estimates of the coefficients if the presence of the third alternative (i.e., nonuse) affects the choice between internal and external commercialization or if factors affecting the censoring procedure (i.e., nonuse) are not independent from the factors affecting commercial use ("selection effects"). To test if our main estimations are subject to these biases, we examined two additional specifications: multinomial logistic regression and the Heckman probit selection model. We also discuss the possibility of bias from omitted observations. However, we do not find any evidence in these robustness checks that invalidate our main specifications (tables available from the contact author).

For the multinomial logistic regression analysis, we created a nominal variable "mode of use” by coding 0 for nonuse, 1 for internal use, and 2 for external use. We did not distinguish between "licensed" and "for a new firm" because of the small number of observations assigned to each of these two 
categories. We ran a multinomial logistic regression with "internal use" as the comparison group. Our multinomial logistic model is proper: the Small-Hsiao tests of Independence of Irrelevant Alternatives (IIA) assumption indicate that we cannot reject the null hypothesis that omission of nonuse is irrelevant to the choice between internal and external use at a 5\% significance level. The multinomial logit model is said to be proper when the outcomes are distinct and not substitutes for one another (Long and Freese, 2006). In our model, the modes of use are distinct, as shown by the results of Wald and Likelihood Ratio tests for combining alternatives. However, they may be substitutes for one another. The probability of mode choice when every patent is forced into use may be different from the probability when nonuse is allowed. For example, if a bargaining failure view of strategic nonuse (Merges, 1994) is valid, then adding or removing a choice for strategic nonuse will affect more on licensing than other choices. Another complexity of interpretation stems from the way we classify the modes of use. We assign those patents in dual use (both internal and external use) to external use. Theoretically, those dual-use patents should have characteristics of both internal and external use and possibly make our interpretation more complex. However, at least empirically, it seems that the characteristics of dual-use patents are more overlapped with the characteristics of external use. We test the distinctiveness of dual use from purely external use using multinomial logistic regression and cannot reject the null hypothesis that they are the same in relation with our covariates (Chi-square $(23)=26.19, \mathrm{p}>$ Chi-square $=0.292$ ). Also, according to some studies, in the situation where IIA is violated, a well-specified multinomial logistic model is comparable in sign and significance of coefficients with nested or mixed logistic models (Cushing and Cushing, 2007; Train, 2003). Indeed, our main estimation binary probit regression in the restricted sample does not show notable differences from the multinomial logistic regression. For the multinomial logistic specification, we obtained estimates for the coefficients on the explanatory variables that were consistent (both in sign and significance) with those from the binary probit specifications.

The Heckman selection model with selection of "any commercial use” in the first stage, addresses the selection bias problem. In the selection equation, we regressed "any commercial use” on six variables: Technological value, Collaboration, No immediate demand, Number of inventors, Age of invention, and 
Component familiarity. The selection probability term fed into the main equation is, however, not significant (Heckman's rho=-0.293; $\mathrm{p}>$ Chi-square=0.647), indicating that our main specifications are not subject to significant bias by removing nonuse patents.

Before we conclude this section, let us briefly address another feasible source of bias-possible self-selection effects related to the missing values on some of the covariates. We examined whether the number of dropped observations had to do with self-selection by running the Heckman probit selection model with a dummy for complete cases as the dependent variable in the selection equation. The selfselection effect is not significant as indicated by insignificant correlations between error terms in the selection equation and error terms in the outcome equation. Also, we ran the main models with imputed values on "technological value" replaced with its mean $(=2.19)$ and its predicted value estimated from the regression equation, respectively. While these imputations increase the sample size by about $16 \%$ (from $\mathrm{N}=1226$ to 1415), we found no notable differences between dummy-adjusted models and the original ones. We also ran the models in the imputed sample using bootstrap re-sampling methods. The basic idea is that, if there is a significant bias due to missing values, then the coefficients and standard errors estimated for the subsample will be different from the original one. We re-sampled 50 random subsamples from the imputed sample $(\mathrm{N}=1415)$ and calculated bootstrap coefficients and standard errors. The results are consistent with the results of our main models. Furthermore, we found no significant difference in the means of our dependent variables between the full set $(\mathrm{N}=1807)$ and the uncensored subset $(\mathrm{N}=1226)$. However, even if list-wise deletions are not totally random to some extent, this does not indicate that we will have biased estimates for the following reasons: first, our sample is not censored by the characteristics of the dependent variables (Wooldridge, 2002). Second, the signs and significance of the coefficients in the binary probit models are almost identical to those in the probit selection models, which suggests that the bias from omitting the selection correction term is small. Therefore, using the binary probit analysis for the complete cases is appropriate. 


\subsubsection{Endogeneity of the explanatory variables}

Although we control for many factors at the invention and firm levels, we cannot control for firm strategy or a management tendency toward internal commercialization that may affect both the internal commercialization decision and some of our explanatory variables. To test the significance of endogeneity, we estimated bivariate and multivariate probit models using an instrument variable (Greene, 2003). Fortunately, we have a good instrument that only affects Manufacturing unit and Improvement but not the governance choice of commercialization. In the survey, we asked if the invention was an outcome of pure inspiration or from one's normal job not related to inventing and was not further developed in an $\mathrm{R} \& \mathrm{D}$ project. This variable is related to Manufacturing unit and Improvement because of the exclusion of formal R\&D. However, its impacts on the governance choice are not clear. Indeed, the indicator variable for purely inspirational inventions is correlated with Manufacturing unit (chi-square $=12.30 ; \mathrm{P}<0.00$ ) and Improvement (chi-square=6.31; $\mathrm{P}<0.01$ ) but not with Internal commercialization (chi-square=0.47; $\mathrm{P}<0.49$ ). Based on both the bivariate and multivariate estimations we cannot reject the null hypothesis that the error terms of the main equation and instrumented equation, in which we regress Manufacturing unit (or Improvement) on the indicator of pure inspirational inventions, are related as indicated by insignificant estimates of covariance of error terms in all specifications. To sum, we do not find evidence that Manufacturing unit and Improvement are endogenous.

\section{Discussion and Conclusion}

\subsection{Discussion and implications}

In this paper we build on the TCE, capabilities theories and embeddedness perspectives to explain why firms choose different modes of commercializing their patented inventions. In particular, we used arguments developed in transaction costs economics to explain how technological uncertainty and asset specificity affect the exchange conditions and, therefore, the governance choice in commercializing patented inventions. Conforming to TCE and our arguments, our empirical test shows that the more 
familiar the technology, the more likely a patented invention is commercialized externally. This finding sheds light on the influence of technology evolution (or industry evolution) on governance choice.

Based on both TCE and arguments from the literature about capabilities, we argue that strong coupling with a firm's existing capabilities raises the propensity of internal commercialization. In our arguments, we show that both TCE and capability-based logics lead to consistent prediction, although with different focuses: exchange conditions for TCE and production conditions for capability-based theories. This may be due in part because in many cases capabilities are confounded with exchange conditions. This suggests the need for further work that explores how exchange conditions interact with firm capabilities (Argyres and Zenger, 2008; Jacobides and Winter, 2005). We examined one facet of capabilities-exchange co-evolution by testing how the impacts of firm production capabilities on internal commercialization change depending on technology familiarity (H2b, Figure 1). We found evidence that macro-level environment conditions that affect exchange conditions (such as technology familiarity) moderate the effects of capabilities on governance choice. One practical implication of this finding is that, for example, the value of co-specialized assets, as identified by a sharper incentive to use inventions internally, will be higher for an emerging technology than a mature technology.

Finally, as Poppo and Zenger (2002) contended, and the growing literature on open innovation and network relationships argue, existing studies about governance choice have not given sufficient attention to the effects of inter-firm ties on governance choice (although TCE has begun to incorporate relational contracting into the model, see Williamson, 1991, 2002). This study shows that R\&D collaboration influences commercialization strategy, even after controlling for the effects of knowledge flows. We show that a particular type of inter-firm ties, horizontal inventive collaboration, raises the propensity of external commercialization. We suggest that this is due to increased trust built up during the invention process that carries over to influence the commercialization strategy, complemented by relational inertia. At the same time, information spillovers during the collaborative $R \& D$ project may reduce the exclusivity advantage of in-house use (or put differently, rent dissipation may have already occurred), lowering some of the constraints on external commercialization. Future work is needed to 
clarify which of these mechanisms is most dominant in determining commercialization mode. We do not find strong evidence that horizontal collaboration moderates the negative effects of high technology uncertainty on market contracts (in contrast to Uzzi 1997 and Powell 1990).

This paper contributes to the literature in the following points. First, it shows that theoretical constructs from the evolutionary explanation of technology development (Abernathy and Clark, 1985;

Dosi, 1982; Henderson and Clark, 1990; Utterback, 1994) and Teece’s dominant design explanation have some explanatory power in the governance choice of commercializing patented inventions. In particular, we show that technological maturity is associated with more developed markets for technology. We also confirm that TCE provides valuable guidance in understanding the governance structure for innovations. While much of the TCE research focuses on the make-or-buy decision, we are extending this line of research by focusing on the integrate-or-license decisions in the innovation context, providing empirical support for the TCE-based predictions. Moreover, whereas most existing studies on licensing consider the rate of licensing at the firm or industry levels, we directly compare the propensity of external commercialization with internal commercialization at the level of individual inventions, directly testing the governance choice for a particular set of invention characteristics.

We also find evidence that co-specialized complementary assets are important for choice of commercialization mode. Finally, we find that embedded ties built during the invention process have strong effects on the commercialization process. Prior work has shown that structural embeddedness has important impacts on firm invention productivity (Owen-Smith and Powell, 2004). Previous studies showed how particular ties (Afuah, 2000; Dyer and Nobeoka, 2000; Gulati and Higgins, 2003; Uzzi, 1996) or breadth/depth of external search (Katila and Ahuja, 2002) affect the firm or innovation performance. Future work can develop these insights by examining the effects of whole network structural embeddedness (and structural holes) on governance choice (Jones et al., 1997a).

\subsection{Limitations and future avenues of research}

While our results are robust to a variety of specifications and tests for selection and endogeneity, there are still some important limitations. While we include a broad set of covariates at the technology, 
firm, invention, and project levels, we do not control for firm-specific fixed effects because our data set is cross-sectional. The study also does not directly test implications of product market characteristics or industry structure. Instead, it controls for broad industry areas and the characteristics of technology fields. Also, a fuller understanding of external commercialization will be possible when we can consider dyadic relationships and full network structures as well as aspects of financial markets, which we do not address in the study.

Finally, the study compares out-licensing versus in-house use. However, technologies can be simultaneously used in house and licensed. This dual strategy might be especially important under certain conditions. For example, Parmigiani and Mitchell (2009) argue that, in the face of uncertainty, firms having expertise in multiple component technologies would source the components from both internal and external sources rather than from purely internal sources to hedge the risks of unpredicted demand fluctuation and to absorb external knowledge. Their arguments are premised on the assumption that firms know more than they produce (Brusoni et al., 2001) so that outsourcing firm’s knowledge in the components can successfully eradicate the hold-up hazards. Their arguments ground the discussion on an additional dimension different from TCE and capabilities. Although their arguments are not directly applicable to commercializing patented inventions, which address the 'make-or-license decision instead of a 'make-or-buy' decision, their risk-hedging arguments still hold. However, this logic provides a similar prediction on the impact of a strong coupling between an invention and existing capabilities on the boundary decision - the strong coupling as a precondition for concurrent sourcing works counter to the force toward integration caused by capability and TCE logics. Because of a limited number of dual use cases, we were not able to explore this in detail. However, future work might focus on this dual use and the strategic advantages and costs of such forms of technology commercialization.

Our results show that technology familiarity, firm capabilities and embedded ties are all important drivers of commercialization strategy. In doing so, we attempt to integrate TCE, firm capabilities and network perspectives on governance of innovation. Although we were not able to present clear cut boundaries between each construct in terms of its effects and scope conditions on governance choice, we 
suggest that this synthetic view can deepen our understanding of the interrelationships among trust,

knowledge and capability dependency, exchange conditions and governance choice.

\section{References}

Abernathy, W.J., Clark, K.B., 1985. Innovation: Mapping the winds of creative destruction. Research Policy 14, 3-22.

Achrol, R., 1997. Changes in the theory of interorganizational relations in marketing: Toward a network paradigm. Journal of the Academy of Marketing Science 25, 56-71.

Afuah, A., 2000. How much do your co-opetitors' capabilities matter in the face of technological change? Strategic Management Journal 21, 397-404.

Afuah, A., 2003. Innovation Management: Strategies, Implementation and Profits. Oxford University Press.

Ai, C., Norton, E.C., 2003. I nteraction terms in logit and probit models. Economics Letters 80, 123-129. Anderson, P., Tushman, M.L., 1990. Technological Discontinuities and Dominant Designs: A Cyclical Model of Technological Change. Administrative Science Quarterly 35, 604-633.

Argyres, N.S., 1996. Evidence on the Role of Firm Capabilities in Vertical Integration Decisions. Strategic Management Journal 17, 129-150.

Argyres, N.S., Zenger, T.R., 2008. Capabilities, Transaction Costs, and Firm Boundaries: A Dynamic Perspective and Integration. SSRN eLibrary.

Arora, A., Ceccagnoli, M., 2006. Patent Protection, Complementary Assets, and Firms' Incentives for Technology Licensing. Management Science 52, 293-308.

Arora, A., Fosfuri, A., 2003. Licensing the market for technology. Journal of Economic Behavior \& Organization 52, 277-295.

Arora, A., Fosfuri, A., Gambardella, A., 2001. Markets for Technology: The Economics of Innovation and Corporate Strategy. MIT Press, Cambridge, MA.

Arthur, W.B., 2007. The structure of invention. Research Policy 36, 274-287.

Brusoni, S., Prencipe, A., Pavitt, K., 2001. Knowledge Specialization, Organizational Coupling, and the Boundaries of the Firm: Why Do Firms Know More Than They Make? Administrative Science Quarterly 46, 597-621.

Cohen, W.M., Levinthal, D.A., 1989. Innovation and Learning: The Two Faces of R \& D. Economic Journal 99, 569-596.

Cohen, W.M., Levinthal, D.A., 1990. Absorptive Capacity: A New Perspective on Learning and Innovation. Administrative Science Quarterly 35, 128-152.

Cohen, W.M., Nelson, R.R., Walsh, J.P., 2000. Protecting Their Intellectual Assets: Appropriability Conditions and Why US Manufacturing Firms Patent (or Not). NBER Working Paper.

Coleman, J.S., 1988. Social Capital in the Creation of Human Capital. American Journal of Sociology 94. Conner, K.R., Prahalad, C.K., 1996. A Resource-based Theory of the Firm: Knowledge Versus Opportunism. Organization Science 7, 477-501.

Cushing, C., Cushing, B., 2007. Conditional Logit, IIA, and Alternatives for Estimating Models of Interstate Migration, 46th annual meeting of the Southern Regional Science Association, Charleston, SC. Dosi, G., 1982. Technological paradigms and technological trajectories. Research Policy 11, 147-162. Dyer, J.H., Chu, W., 2000. The Determinants of Trust in Supplier-automaker Relationships in the U.S., Japan, and Korea. Journal of International Business Studies 31, 259-285.

Dyer, J.H., Nobeoka, K., 2000. Creating and Managing a High-Performance Knowledge-Sharing Network: The Toyota Case. Strategic Management Journal 21, 345.

Fleming, L., 2001. Recombinant Uncertainty in Technological Search. Management Science 47, 117. Fleming, L., Sorenson, O., 2001. Technology as a complex adaptive system: Evidence from patent data. Research Policy 30, 1019-1039. 
Galaskiewicz, J., 1985. Interorganizational Relations. Annual Review of Sociology 11, 281-304.

Gambardella, A., Giuri, P., Luzzi, A., 2007. The market for patents in Europe. Research Policy 36, 1163-

1183.

Gambardella, A., Harhoff, D., Verspagen, B., 2008. The value of European patents. European

Management Review 5, 69-84.

Granovetter, M., 1985. Economic Action and Social Structure: The Problem of Embeddedness. American

Journal of Sociology 91, 481-510.

Greene, W.H., 2003. Econometric analysis, 5 ed. Prentice Hall, Upper Saddle River, NJ.

Grimpe, C., Hussinger, K., 2008. Building and Blocking: The Two Faces of Technology Acquisition.

ZEW Discussion Paper 08-042.

Gulati, R., Higgins, M.C., 2003. Which ties matter when? the contingent effects of interorganizational

partnerships on IPO success. Strategic Management Journal 24, 127-144.

Hall, B.H., 1990. The Manufacturing Sector Master File: 1959-1987. NBER Working Paper 3366.

Harhoff, D., Narin, F., Scherer, F.M., Vopel, K., 1999. Citation Frequency and the Value of Patented

Inventions. Review of Economics \& Statistics 81, 511-515.

Henderson, R.M., Clark, K.B., 1990. Architectural Innovation: The Reconfiguration of Existing Product

Technologies and the Failure of Established Firms. Administrative Science Quarterly 35, 9-30.

Hoetker, G., 2007. The use of logit and probit models in strategic management research: Critical issues.

Strategic Management Journal 28, 331-343.

Holmstrom, B., Roberts, J., 1998. The Boundaries of the Firm Revisited. Journal of Economic

Perspectives 12, 73-94.

Jacobides, M.G., Winter, S.G., 2005. The co-evolution of capabilities and transaction costs: explaining

the institutional structure of production. Strategic Management Journal 26, 395-413.

Jones, C., Hesterly, W.S., Borgatti, S.P., 1997a. A general theory of network governance: exchange

conditions and social mechanisms. Academy of Management Review.

Jones, C., Hesterly, W.S., Borgatti, S.P., 1997b. A general theory of network governance: Exchange

conditions and social mechanisms. Academy of Management Review 22, 911-945.

Jung, T., 2009. Uses and nonuses of patented inventions, Public Policy. Georgia Institute of Technology, Atlanta.

Katila, R., Ahuja, G., 2002. Something Old, Something New: A Longitudinal Study of Search Behavior and New Product Development. Academy of Management Journal 45, 1183-1194.

Kim, Y., Vonortas, N.S., 2006. Determinants of technology licensing: the case of licensors. Managerial and Decision Economics 27, 235-249.

Kogut, B., Zander, U., 1992. Knowledge of the Firm, Combinative Capabilities, and the Replication of Technology. Organization Science 3, 383-397.

Lai, R., D’Amour, A., Fleming, L., 2009. The careers and co-authorship networks of US patent-holders

since 1975, Harvard Business School, Boston, MA.

Lanjouw, J.O., Schankerman, M., 2004. Patent Quality and Research Productivity: Measuring Innovation with Multiple Indicators. Economic Journal 114, 441-465.

Leiblein, M.J., Miller, D.J., 2003. An empirical examination of transaction- and firm-level influences on the vertical boundaries of the firm. Strategic Management Journal 24, 839-859.

Long, J.S., Freese, J., 2006. Regression Models for Categorical Dependent Variables Using Stata. Stata

Press.

March, J.G., 1991. Exploration and Exploitation in Organizational Learning. Organization Science 2, 71-

87.

McEvily, B., Marcus, A., 2005. Embedded ties and the acquisition of competitive capabilities. Strategic

Management Journal 26, 1033-1055.

Merges, R.P., 1994. Intellectual Property Rights and Bargaining Breakdown: The Case of Blocking

Patents. Tennessee Law Review 62, 75-106.

Mitchell, W., 1991. Dual clocks: Entry order influences on incumbent and newcomer market share and survival when specialized assets retain their value. Strategic Management Journal 12, 85-100. 
Mowery, D.C., Oxley, J.E., Silverman, B.S., 1996. Strategic Alliances and Interfirm Knowledge Transfer. Strategic Management Journal 17, 77-91.

Nelson, R.R., Winter, S.G., 1982. An Evolutionary Theory of Economic Change. Harvard University

Press, Cambridge, Mass.

Nerkar, A., Shane, S., 2007. Determinants of invention commercialization: an empirical examination of academically sourced inventions. Strategic Management Journal 28, 1155-1166.

Norton, E.C., Wang, H., Ai, C., 2004. Computing interaction effects and standard errors in logit and Probit models. Stata Journal 4, 154-167.

OECD, 1994. Using Patent Data as Scientific and Technology Indicators - Patent Manual. Organization

for Economic Co-operation and Development, Paris.

OECD, 2006. The OECD Database on Triadic Patent Families.

Owen-Smith, J., Powell, W.W., 2004. Knowledge Networks as Channels and Conduits: The Effects of Spillovers in the Boston Biotechnology Community. Organization Science 15, 5-21.

Oxley, J.E., 1997. Appropriability Hazards and Governance in Strategic Alliances: A Transaction Cost Approach. Journal of Law, Economics, \& Organization 13, 387-409.

Oxley, J.E., 1999. Institutional environment and the mechanisms of governance: the impact of intellectual property protection on the structure of inter-firm alliances. Journal of Economic Behavior \& Organization 38, 283-309.

Parmigiani, A., Mitchell, W., 2009. Complementarity, capabilities, and the boundaries of the firm: the impact of within-firm and interfirm expertise on concurrent sourcing of complementary components. Strategic Management Journal 30, 1065-1091.

Podolny, J.M., Page, K.L., 1998. Network Forms of Organization. Annual Review of Sociology 24, 57-76. Poppo, L., Zenger, T., 1998. Testing alternative theories of the firm: transaction cost, knowledge-based, and measurement explanations for make-or-buy decisions in information services. Strategic Management Journal 19, 853-877.

Poppo, L., Zenger, T., 2002. Do formal contracts and relational governance function as substitutes or complements? Strategic Management Journal 23, 707-725.

Powell, W.W., 1990. Neither market nor hierarchy: network forms of organization, in: Staw, B., Cummings, L.L. (Eds.), Research in Organizational Behavior. JAI Press, Greenwich, CT, pp. 295-336.

Powell, W.W., Koput, K.W., Smith-Doerr, L., 1996. Interorganizational Collaboration and the Locus of Innovation: Networks of Learning in Biotechnology. Administrative Science Quarterly 41, 116-145.

Roberts, E.B., 1988. Managing Invention and Innovation. Research Technology Management 31, 11-27. Rothaermel, F.T., Deeds, D.L., 2004. Exploration and Exploitation Alliances in Biotechnology: A System of New Product Development. Strategic Management Journal 25, 201-221.

Schumpeter, J.A., 1942. Capitalism, Socialism and Democracy. HarperPerennial.

Stinchcombe, A.L., 1990. Information and Organizations. University of California Press, Berkeley.

Stuart, T.E., Hoang, H., Hybels, R.C., 1999. Interorganizational Endorsements and the Performance of Entrepreneurial Ventures. Administrative Science Quarterly 44, 315-349.

Teece, D.J., 1986. Profiting from technological innovation: Implications for integration, collaboration, licensing and public policy. Research Policy 15, 285-305.

Tomz, M., Wittenberg, J., King, G., 2003. Clarify: Software for Interpreting and Presenting Statistical Results. Journal of Statistical Software 8.

Train, K., 2003. Discrete Choice Methods with Simulation. Cambridge University Press, Cambridge, MA. Tushman, M.L., Anderson, P., 1986. Technological Discontinuities and Organizational Environments. Administrative Science Quarterly 31, 439-465.

Utterback, J.M., 1994. Mastering the Dynamics of Innovation. Harvard Business School Press, Boston, MA.

Uzzi, B., 1996. The sources and consequences of embeddedness for the economic performance of organizations: the network effect. American Sociological Review 61, 674-698.

Uzzi, B., 1997. Social Structure and Competition in Interfirm Networks: The Paradox of Embeddedness. Administrative Science Quarterly 42, 37-69. 
Uzzi, B., Spiro, J., 2005. Collaboration and Creativity: The Small World Problem. American Journal of Sociology 111, 447-504.

von Hippel, E., 1988. The Sources of Innovation. Oxford University Press.

Williamson, O.E., 1985. The Economic Institutions of Capitalism: Firms, markets, relational contracting. Free Press, New York.

Williamson, O.E., 1991. Comparative Economic Organization: The Analysis of Discrete Structural Alternatives. Administrative Science Quarterly 36, 269-296.

Williamson, O.E., 2002. The Theory of the Firm as Governance Structure: From Choice to Contract. Journal of Economic Perspectives 16, 171-195.

Wooldridge, J.M., 2002. Econometric Analysis of Cross Section and Panel Data. MIT Press, Cambridge, Massachusetts.

Zaheer, A., McEvily, B., Perrone, V., 1998. Does Trust Matter? Exploring the Effects of Interorganizational and Interpersonal Trust on Performance. Organization Science 9, 141-159.

Zajac, E.J., Olsen, C.P., 1993. From Transaction Costs to Transactional Value Analysis: Implications for the Study of Interorganizational Strategies. Journal of Management Studies 30, 131-145.

Zelner, B.A., 2009. Using simulation to interpret results from logit, probit, and other nonlinear models. Strategic Management Journal 30, 1335-1348. 


\section{Table A. 1 Correlation matrix $(\mathrm{N}=651)$}

\begin{tabular}{|c|c|c|c|c|c|c|c|c|c|c|c|c|c|c|c|c|c|c|c|c|c|c|c|c|}
\hline 1 & Internal commercialization & 1 & 2 & 3 & 4 & 5 & 6 & 7 & 8 & 9 & 10 & 11 & 12 & 13 & 14 & 15 & 16 & 17 & 18 & 19 & 20 & 21 & 22 & 23 \\
\hline 2 & Component familiarity & $-0.12^{*}$ & 1 & & & & & & & & & & & & & & & & & & & & & \\
\hline 3 & Manufacturing unit & $0.09 *$ & -0.06 & 1 & & & & & & & & & & & & & & & & & & & & \\
\hline 4 & $2 * 3$ & 0 & $0.09 *$ & $0.62 *$ & 1 & & & & & & & & & & & & & & & & & & & \\
\hline 5 & Improvement & $0.11^{*}$ & -0.02 & 0.01 & -0.03 & 1 & & & & & & & & & & & & & & & & & & \\
\hline 6 & $2 * 5$ & -0.03 & $0.6^{*}$ & -0.05 & 0.02 & $0.39 *$ & 1 & & & & & & & & & & & & & & & & & \\
\hline 7 & Horizontal collaboration & $-0.11^{*}$ & -0.04 & -0.04 & -0.04 & -0.07 & -0.04 & 1 & & & & & & & & & & & & & & & & \\
\hline 8 & $2 * 7$ & $-0.1 *$ & 0.06 & -0.04 & -0.02 & -0.05 & 0.01 & $0.71 *$ & 1 & & & & & & & & & & & & & & & \\
\hline 9 & Vertical collaboration & 0.05 & $-0.08^{*}$ & 0.01 & -0.03 & $-0.09 *$ & -0.06 & $0.21 *$ & $0.15^{*}$ & 1 & & & & & & & & & & & & & & \\
\hline 10 & Public collaboration & $-0.1^{*}$ & 0.04 & -0.02 & -0.01 & -0.05 & -0.02 & $0.13 *$ & $0.08^{*}$ & $0.13^{*}$ & 1 & & & & & & & & & & & & & \\
\hline 11 & Industrial knowledge & 0.03 & -0.05 & 0.02 & $0.08 *$ & $-0.11 *$ & -0.04 & $0.1^{*}$ & 0.05 & $0.28 *$ & $0.15^{*}$ & 1 & & & & & & & & & & & & \\
\hline 12 & Public knowledge & $-0.18 *$ & $0.11^{*}$ & -0.06 & 0.02 & $-0.13 *$ & 0.04 & $0.09 *$ & 0.07 & $0.09 *$ & $0.38 *$ & $0.47 *$ & 1 & & & & & & & & & & & \\
\hline 13 & Large firm & $0.23^{*}$ & -0.04 & $-0.1^{*}$ & $-0.11 *$ & 0.04 & -0.06 & 0.02 & 0.02 & -0.02 & $-0.15^{*}$ & -0.01 & -0.07 & 1 & & & & & & & & & & \\
\hline 14 & Ln(patent stock) & $0.12 *$ & 0.01 & $-0.11^{*}$ & $-0.1^{*}$ & 0.04 & -0.02 & -0.06 & -0.03 & $-0.14 *$ & $-0.12 *$ & $-0.11 *$ & -0.05 & $0.58 *$ & 1 & & & & & & & & & \\
\hline 15 & Technological value & $-0.13 *$ & -0.01 & -0.01 & 0.01 & $-0.12 *$ & -0.08 & 0 & -0.02 & 0.05 & $0.08^{*}$ & $0.11^{*}$ & $0.18^{*}$ & $-0.12 *$ & $-0.13 *$ & 1 & & & & & & & & \\
\hline 16 & No immediate demand & 0.01 & 0.01 & -0.04 & -0.06 & 0.06 & 0.02 & -0.02 & -0.03 & 0.03 & -0.02 & -0.01 & $0.1^{*}$ & -0.01 & 0.02 & $0.1^{*}$ & 1 & & & & & & & \\
\hline 17 & $\%$ Basic R\&D & $-0.08^{*}$ & 0.04 & -0.05 & -0.02 & $-0.11 *$ & -0.04 & 0.07 & 0.02 & 0.01 & $0.14 *$ & $0.11 *$ & $0.26 *$ & -0.01 & 0.02 & $0.13^{*}$ & $0.11^{*}$ & 1 & 1 & & & & & \\
\hline 18 & Product invention & 0.07 & -0.04 & 0.01 & -0.02 & 0.05 & -0.04 & -0.03 & -0.03 & -0.03 & 0.01 & 0.07 & -0.04 & 0.02 & 0.02 & -0.07 & -0.03 & -0.08 & 1 & & & & & \\
\hline 19 & Man-months & $-0.08^{*}$ & -0.02 & -0.04 & -0.04 & $-0.12 *$ & -0.07 & 0.06 & 0.02 & 0.07 & 0.07 & $0.15^{*}$ & $0.22 *$ & -0.02 & 0.04 & $0.15^{*}$ & 0 & 0.07 & $7 \quad-0.07$ & 1 & & & & \\
\hline 20 & Number of inventors & 0.01 & 0.02 & -0.07 & -0.06 & -0.02 & 0.03 & 0.02 & 0 & -0.05 & -0.02 & 0.06 & 0.04 & 0.05 & $0.1^{*}$ & 0.05 & -0.02 & 0.02 & $2-0.04$ & $0.29 *$ & 1 & & & \\
\hline 21 & Complexity of technology & -0.02 & 0.06 & -0.08 & -0.05 & -0.02 & 0.01 & -0.06 & -0.05 & 0.02 & 0.05 & 0.05 & $0.1^{*}$ & 0.01 & -0.05 & $0.12 *$ & 0 & $0.1^{*}$ & ${ }^{*}-0.09 *$ & 0.01 & -0.03 & 1 & & \\
\hline 22 & Number of claims & -0.05 & -0.04 & -0.05 & -0.01 & -0.04 & 0.01 & 0.01 & -0.02 & 0 & 0.03 & -0.01 & -0.07 & $-0.11 *$ & $-0.14 *$ & $0.11^{*}$ & -0.03 & -0.02 & $2-0.05$ & 0.02 & $0.09 *$ & 0.07 & 1 & \\
\hline 23 & Age of invention (months) & -0.01 & -0.02 & 0.07 & 0.07 & -0.02 & 0.02 & -0.05 & -0.04 & 0 & 0.02 & $0.09 *$ & $0.12 *$ & $0.1^{*}$ & $0.13 *$ & -0.07 & 0 & 0.01 & $1-0.03$ & 0.02 & 0 & 0.05 & $-0.1^{*}$ & 1 \\
\hline 24 & Electrical engineering & -0.04 & $0.11^{*}$ & -0.06 & -0.01 & -0.05 & 0.05 & -0.02 & & $-0.09 *$ & $=-0.04$ & $-0.09 *$ & 0.01 & 0.05 & $0.14 *$ & -0.01 & 0.05 & 0.03 & 30.03 & -0.06 & -0.08 & -0.06 & -0.01 & $0.08^{*}$ \\
\hline 25 & Chemistry, pharmaceuticals & -0.06 & $0.14 *$ & -0.08 & 0.01 & -0.02 & 0.07 & -0.01 & 0.03 & -0.04 & $0.09 *$ & 0.07 & $0.17^{*}$ & 0.03 & -0.05 & 0.04 & 0 & $0.15^{*}$ & ${ }^{*}-0.11 *$ & $0.09 *$ & 0.05 & $0.26 *$ & -0.03 & -0.04 \\
\hline 26 & Process & -0.01 & -0.08 & 0.02 & -0.02 & 0.03 & -0.06 & 0.05 & 0.01 & 0.04 & -0.04 & -0.01 & $-0.14^{*}$ & 0.03 & -0.01 & -0.02 & -0.04 & -0.02 & $-0.1^{*}$ & -0.06 & -0.01 & 0.06 & -0.01 & -0.02 \\
\hline 27 & Mechanical eng, machinery & $0.14^{*}$ & $-0.15^{*}$ & $0.14 *$ & -0.01 & 0.01 & $-0.08^{*}$ & -0.02 & -0.04 & 0.08 & -0.06 & -0.03 & $-0.14 *$ & 0.01 & -0.02 & -0.01 & 0.02 & $-0.11 *$ & * $0.11 *$ & -0.06 & $-0.1^{*}$ & $-0.13^{*}$ & 0 & -0.04 \\
\hline 28 & Consumer goods & 0.01 & -0.07 & 0.06 & 0 & -0.04 & -0.04 & 0.06 & 0 & 0.02 & 0.01 & $0.08 *$ & -0.05 & $-0.1^{*}$ & $-0.09 *$ & 0.02 & -0.08 & -0.04 & $40.12 *$ & 0.02 & -0.02 & -0.02 & 0.05 & $\underline{0}$ \\
\hline
\end{tabular}

* denotes 5\% significance level 
Table 1. Sample statistics $(\mathrm{N}=651)$.

\begin{tabular}{|c|c|c|c|c|c|}
\hline Variable & Mean & Std. Dev. & Min & Max & Data source \\
\hline $\begin{array}{l}\text { Internal commercialization } \\
\text { Explanatory variables }\end{array}$ & 0.737 & 0.440 & 0 & 1 & Survey \\
\hline Component familiarity (/1000) & 0.087 & 0.151 & 0.000 & 2.081 & USPTO \\
\hline Manufacturing unit & 0.108 & 0.311 & 0 & 1 & Survey \\
\hline Improvement invention & 0.427 & 0.495 & 0 & 1 & Survey \\
\hline $\begin{array}{c}\text { Horizontal collaboration - } \\
\text { Controls }\end{array}$ & 0.075 & 0.263 & 0 & 1 & Survey \\
\hline Vertical collaboration & 0.272 & 0.445 & 0 & 1 & Survey \\
\hline Public collaboration & 0.070 & 0.256 & 0 & 1 & Survey \\
\hline Industrial knowledge & 0.293 & 0.196 & 0 & 1 & Survey \\
\hline Public knowledge & 0.255 & 0.209 & 0 & 0.900 & Survey \\
\hline Large firm (employees >500) & 0.824 & 0.381 & 0 & 1 & Survey \& Patent \\
\hline Capital intensity (M\$/employee) & 0.058 & 0.088 & 0 & 0.823 & COMPUSTAT \\
\hline Dummy for missing capital intensity & 0.321 & 0.467 & 0 & 1 & COMPUSTAT \\
\hline Ln(patent stock) & 5.014 & 2.800 & 0 & 9.865 & PATSTAT \\
\hline Technological value & 2.427 & 1.087 & 1 & 4 & Survey \\
\hline No immediate demand & 0.186 & 0.390 & 0 & 1 & Survey \\
\hline \% Basic R\&D (/100) & 0.067 & 0.153 & 0 & 1 & Survey \\
\hline Product invention & 0.536 & 0.499 & 0 & 1 & Survey \\
\hline Man-months & 0.193 & 0.229 & 0.005 & 1 & Survey \\
\hline Number of inventors & 2.899 & 1.983 & 1 & 16 & Patent \\
\hline Complexity of technology (\# USPC) & 4.310 & 3.305 & 1 & 23 & Patent \\
\hline Number of claims & 22.823 & 16.997 & 1 & 181 & Patent \\
\hline Age of invention (months) & 69.276 & 12.002 & 38 & 92 & Patent \\
\hline Electrical engineering & 0.258 & 0.438 & 0 & 1 & Patent \\
\hline Instruments & 0.198 & 0.399 & 0 & 1 & Patent \\
\hline Chemistry, pharmaceuticals & 0.220 & 0.414 & 0 & 1 & Patent \\
\hline Process eng, special equipment & 0.144 & 0.351 & 0 & 1 & Patent \\
\hline Mechanical eng, machinery & 0.142 & 0.349 & 0 & 1 & Patent \\
\hline Consumer goods \& Construction & 0.038 & 0.192 & 0 & 1 & Patent \\
\hline
\end{tabular}


Table 2. Probit regression of internal commercialization on familiarity, links to capabilities and

inter-organizational ties.

\begin{tabular}{|c|c|c|c|c|c|c|c|}
\hline & \multirow{2}{*}{$\begin{array}{c}\begin{array}{c}\text { Base } \\
\text { Model }\end{array} \\
(1) \\
\end{array}$} & \multicolumn{2}{|c|}{ Full models } & \multicolumn{2}{|c|}{ Adding interaction terms } & \multicolumn{2}{|c|}{ Marginal Effects } \\
\hline & & (2) & (3) & (4) & (5) & Large firm & Small firm \\
\hline $\begin{array}{l}\text { Component familiarity } \\
(/ 1000)\end{array}$ & & $\begin{array}{c}-0.684^{* *} \\
(0.338)\end{array}$ & $\begin{array}{l}-0.681^{*} \\
(0.353)\end{array}$ & $\begin{array}{l}-0.666 \\
(0.435)\end{array}$ & $\begin{array}{l}-0.590^{*} \\
(0.344)\end{array}$ & $\begin{array}{l}-0.173^{*} \\
(0.102)\end{array}$ & $\begin{array}{l}-0.235^{*} \\
(0.137)\end{array}$ \\
\hline Manufacturing unit & & & $\begin{array}{l}0.479 * * \\
(0.213)\end{array}$ & & $\begin{array}{l}0.682^{* *} \\
(0.296)\end{array}$ & $\begin{array}{c}0.146^{* * * *} \\
(0.048)\end{array}$ & $\begin{array}{c}0.252 * * * \\
(0.098)\end{array}$ \\
\hline $\begin{array}{l}\text { Component familiarity } \\
* \text { Manufacturing unit }\end{array}$ & & & & & $\begin{array}{l}-2.682 \\
(2.618)\end{array}$ & $\begin{array}{l}-0.788 \\
(0.784)\end{array}$ & $\begin{array}{l}-1.070 \\
(1.044)\end{array}$ \\
\hline Improvement & & $\begin{array}{l}0.270^{* *} \\
(0.119)\end{array}$ & & $\begin{array}{l}0.271^{* *} \\
(0.133)\end{array}$ & & & \\
\hline $\begin{array}{l}\text { Component familiarity } \\
\text { * Improvement }\end{array}$ & & & & $\begin{array}{l}-0.019 \\
(0.689)\end{array}$ & & & \\
\hline Horizontal collaboration & & $\begin{array}{c}-0.627 * * * \\
(0.201)\end{array}$ & $\begin{array}{c}-0.612^{* * *} \\
(0.201)\end{array}$ & $\begin{array}{c}-0.579 * * \\
(0.266)\end{array}$ & $\begin{array}{c}-0.552^{* *} \\
(0.264)\end{array}$ & $\begin{array}{l}-0.188^{*} \\
(0.100)\end{array}$ & $\begin{array}{c}-0.212^{* *} \\
(0.093)\end{array}$ \\
\hline $\begin{array}{l}\text { Component familiarity } \\
\text { * Horizontal collaboration }\end{array}$ & & & & $\begin{array}{l}-0.708 \\
(2.642)\end{array}$ & $\begin{array}{l}-0.837 \\
(2.704)\end{array}$ & $\begin{array}{l}-0.246 \\
(0.795)\end{array}$ & $\begin{array}{l}-0.334 \\
(1.079)\end{array}$ \\
\hline Vertical collaboration & & $\begin{array}{c}0.217 \\
(0.146)\end{array}$ & $\begin{array}{c}0.212 \\
(0.147)\end{array}$ & $\begin{array}{c}0.219 \\
(0.146)\end{array}$ & $\begin{array}{c}0.203 \\
(0.147)\end{array}$ & $\begin{array}{c}0.057 \\
(0.040)\end{array}$ & $\begin{array}{c}0.081 \\
(0.058)\end{array}$ \\
\hline Public collaboration & & $\begin{array}{c}0.098 \\
(0.237)\end{array}$ & $\begin{array}{c}0.103 \\
(0.234)\end{array}$ & $\begin{array}{c}0.096 \\
(0.237)\end{array}$ & $\begin{array}{c}0.089 \\
(0.234)\end{array}$ & $\begin{array}{c}0.025 \\
(0.065)\end{array}$ & $\begin{array}{c}0.036 \\
(0.093)\end{array}$ \\
\hline Industrial knowledge & $\begin{array}{c}1.099 * * * \\
(0.334)\end{array}$ & $\begin{array}{c}1.031^{* * * *} \\
(0.356)\end{array}$ & $\begin{array}{c}0.955 * * * \\
(0.354)\end{array}$ & $\begin{array}{c}1.030 * * * \\
(0.356)\end{array}$ & $\begin{array}{c}1.008^{* * * *} \\
(0.350)\end{array}$ & $\begin{array}{l}0.296 * * * \\
(0.105)\end{array}$ & $\begin{array}{c}0.402 * * * \\
(0.140)\end{array}$ \\
\hline Public knowledge & $\begin{array}{c}-1.458^{* * * *} \\
(0.325)\end{array}$ & $\begin{array}{c}-1.373 * * * \\
(0.349)\end{array}$ & $\begin{array}{c}-1.379 * * * \\
(0.346)\end{array}$ & $\begin{array}{c}-1.371^{* * *} \\
(0.349)\end{array}$ & $\begin{array}{c}-1.379 * * * \\
(0.345)\end{array}$ & $\begin{array}{c}-0.406^{* * *} \\
(0.108)\end{array}$ & $\begin{array}{c}-0.550^{* * * *} \\
(0.138)\end{array}$ \\
\hline Large firm & $\begin{array}{c}0.741^{* * *} \\
(0.176)\end{array}$ & $\begin{array}{c}0.766 * * * \\
(0.179)\end{array}$ & $\begin{array}{c}0.792 * * * \\
(0.183)\end{array}$ & $\begin{array}{c}0.765 * * * \\
(0.179)\end{array}$ & $\begin{array}{c}0.784 * * * \\
(0.184)\end{array}$ & $\begin{array}{c}0.284 * * * \\
(0.071)\end{array}$ & $\begin{array}{c}0.284 * * * \\
(0.071)\end{array}$ \\
\hline Ln(patent stock) & $\begin{array}{l}-0.006 \\
(0.025)\end{array}$ & $\begin{array}{l}-0.007 \\
(0.026)\end{array}$ & $\begin{array}{l}-0.003 \\
(0.026)\end{array}$ & $\begin{array}{l}-0.007 \\
(0.026)\end{array}$ & $\begin{array}{l}-0.003 \\
(0.026)\end{array}$ & $\begin{array}{l}-0.001 \\
(0.008)\end{array}$ & $\begin{array}{l}-0.001 \\
(0.011)\end{array}$ \\
\hline Technological value & $\begin{array}{l}-0.101^{*} \\
(0.057)\end{array}$ & $\begin{array}{l}-0.104 * \\
(0.058)\end{array}$ & $\begin{array}{l}-0.105^{*} \\
(0.058)\end{array}$ & $\begin{array}{l}-0.104^{*} \\
(0.058)\end{array}$ & $\begin{array}{l}-0.104^{*} \\
(0.058)\end{array}$ & $\begin{array}{l}-0.031^{*} \\
(0.017)\end{array}$ & $\begin{array}{l}-0.041^{*} \\
(0.023)\end{array}$ \\
\hline No immediate demand & $\begin{array}{c}0.138 \\
(0.149)\end{array}$ & $\begin{array}{c}0.093 \\
(0.149)\end{array}$ & $\begin{array}{c}0.130 \\
(0.150)\end{array}$ & $\begin{array}{c}0.092 \\
(0.149)\end{array}$ & $\begin{array}{c}0.121 \\
(0.151)\end{array}$ & $\begin{array}{c}0.034 \\
(0.041)\end{array}$ & $\begin{array}{c}0.048 \\
(0.060)\end{array}$ \\
\hline \% Basic R\&D & $\begin{array}{l}-0.148 \\
(0.395)\end{array}$ & $\begin{array}{l}-0.038 \\
(0.405)\end{array}$ & $\begin{array}{l}-0.083 \\
(0.402)\end{array}$ & $\begin{array}{l}-0.043 \\
(0.405)\end{array}$ & $\begin{array}{l}-0.093 \\
(0.403)\end{array}$ & $\begin{array}{l}-0.027 \\
(0.118)\end{array}$ & $\begin{array}{l}-0.037 \\
(0.161)\end{array}$ \\
\hline Product invention & $\begin{array}{c}0.096 \\
(0.115)\end{array}$ & $\begin{array}{c}0.075 \\
(0.116)\end{array}$ & $\begin{array}{c}0.106 \\
(0.116)\end{array}$ & $\begin{array}{c}0.075 \\
(0.117)\end{array}$ & $\begin{array}{c}0.104 \\
(0.116)\end{array}$ & $\begin{array}{c}0.032 \\
(0.036)\end{array}$ & $\begin{array}{c}0.041 \\
(0.046)\end{array}$ \\
\hline Man-months & $\begin{array}{l}-0.296 \\
(0.255)\end{array}$ & $\begin{array}{l}-0.259 \\
(0.266)\end{array}$ & $\begin{array}{l}-0.312 \\
(0.259)\end{array}$ & $\begin{array}{l}-0.262 \\
(0.266)\end{array}$ & $\begin{array}{l}-0.328 \\
(0.259)\end{array}$ & $\begin{array}{l}-0.097 \\
(0.077)\end{array}$ & $\begin{array}{l}-0.131 \\
(0.103)\end{array}$ \\
\hline Number of inventors & $\begin{array}{c}0.028 \\
(0.034)\end{array}$ & $\begin{array}{c}0.037 \\
(0.035)\end{array}$ & $\begin{array}{c}0.037 \\
(0.035)\end{array}$ & $\begin{array}{c}0.036 \\
(0.035)\end{array}$ & $\begin{array}{c}0.035 \\
(0.035)\end{array}$ & $\begin{array}{c}0.010 \\
(0.010)\end{array}$ & $\begin{array}{c}0.014 \\
(0.014)\end{array}$ \\
\hline $\begin{array}{c}\text { Complexity of technology } \\
\text { (\# USPC) }\end{array}$ & $\begin{array}{c}0.015 \\
(0.018)\end{array}$ & $\begin{array}{c}0.011 \\
(0.018)\end{array}$ & $\begin{array}{c}0.014 \\
(0.018)\end{array}$ & $\begin{array}{c}0.011 \\
(0.018)\end{array}$ & $\begin{array}{c}0.013 \\
(0.018)\end{array}$ & $\begin{array}{c}0.004 \\
(0.005)\end{array}$ & $\begin{array}{c}0.005 \\
(0.007)\end{array}$ \\
\hline Number of claims & $\begin{array}{l}-0.004 \\
(0.003)\end{array}$ & $\begin{array}{l}-0.005 \\
(0.003)\end{array}$ & $\begin{array}{l}-0.004 \\
(0.003)\end{array}$ & $\begin{array}{l}-0.005 \\
(0.003)\end{array}$ & $\begin{array}{l}-0.004 \\
(0.003)\end{array}$ & $\begin{array}{l}-0.001 \\
(0.001)\end{array}$ & $\begin{array}{c}-0.002 \\
(0.001)\end{array}$ \\
\hline Age of invention (months) & -0.003 & -0.004 & -0.006 & -0.004 & -0.006 & -0.002 & -0.002 \\
\hline
\end{tabular}




\begin{tabular}{cccccccc} 
& $(0.005)$ & $(0.005)$ & $(0.005)$ & $(0.005)$ & $(0.005)$ & $(0.001)$ & $(0.002)$ \\
Electrical engineering & -0.093 & 0.017 & -0.017 & 0.018 & -0.023 & -0.007 & -0.009 \\
& $(0.166)$ & $(0.168)$ & $(0.167)$ & $(0.168)$ & $(0.167)$ & $(0.049)$ & $(0.067)$ \\
Chemistry, & -0.131 & -0.050 & -0.068 & -0.048 & -0.064 & -0.019 & -0.025 \\
pharmaceuticals & $(0.176)$ & $(0.179)$ & $(0.179)$ & $(0.179)$ & $(0.180)$ & $(0.055)$ & $(0.072)$ \\
Process eng, special & -0.165 & -0.122 & -0.156 & -0.123 & -0.171 & -0.053 & -0.068 \\
equipment & $(0.196)$ & $(0.200)$ & $(0.201)$ & $(0.200)$ & $(0.202)$ & $(0.067)$ & $(0.079)$ \\
Mechanical eng, & $0.551^{* *}$ & $0.599^{* * *}$ & $0.507^{* *}$ & $0.598^{* * *}$ & $0.485^{* *}$ & $0.115^{* * *}$ & $0.186^{* *}$ \\
machinery & $(0.223)$ & $(0.224)$ & $(0.224)$ & $(0.224)$ & $(0.226)$ & $(0.043)$ & $(0.080)$ \\
Consumer goods \& & 0.050 & 0.167 & 0.072 & 0.163 & 0.038 & 0.011 & 0.015 \\
Construction & $(0.307)$ & $(0.320)$ & $(0.310)$ & $(0.320)$ & $(0.311)$ & $(0.089)$ & $(0.124)$ \\
Constant & 0.609 & 0.548 & 0.683 & 0.548 & 0.682 & & \\
\hline Log Likelihood & $(0.435)$ & $(0.455)$ & $(0.449)$ & $(0.457)$ & $(0.451)$ & & \\
Wald chi2 & -330.3 & -321.4 & -321.2 & -321.4 & -320.6 & -320.6 & -320.6 \\
Pseudo R2 & 82.04 & 100.5 & 96.38 & 100.9 & 96.96 & 96.96 & 96.96 \\
& 0.114 & 0.138 & 0.138 & 0.138 & 0.140 & 0.140 & 0.140
\end{tabular}

Robust standard errors in parentheses

* denotes $10 \%$ significance level, ** denotes 5\% significance level, *** denotes $1 \%$ significance level 


\section{Figure 1 Interaction effects of component familiarity and manufacturing unit}

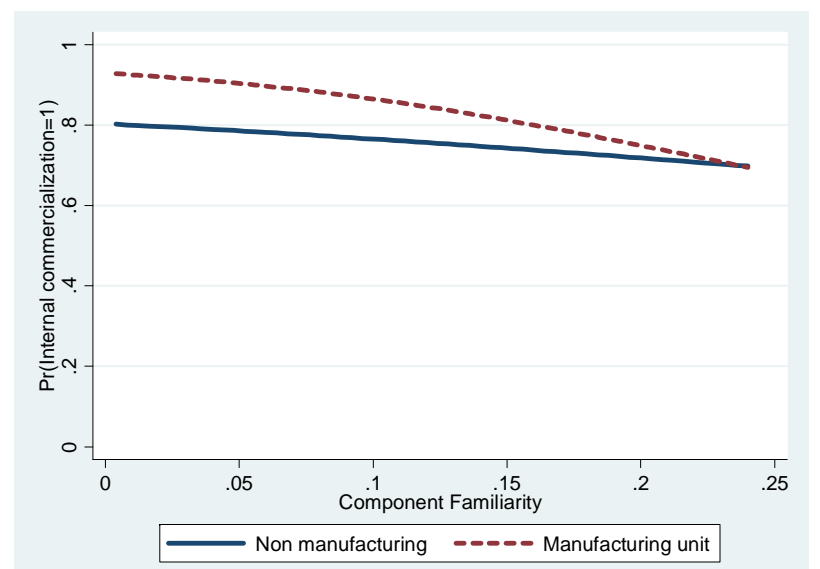

(a) Predicted probability of internal commercialization

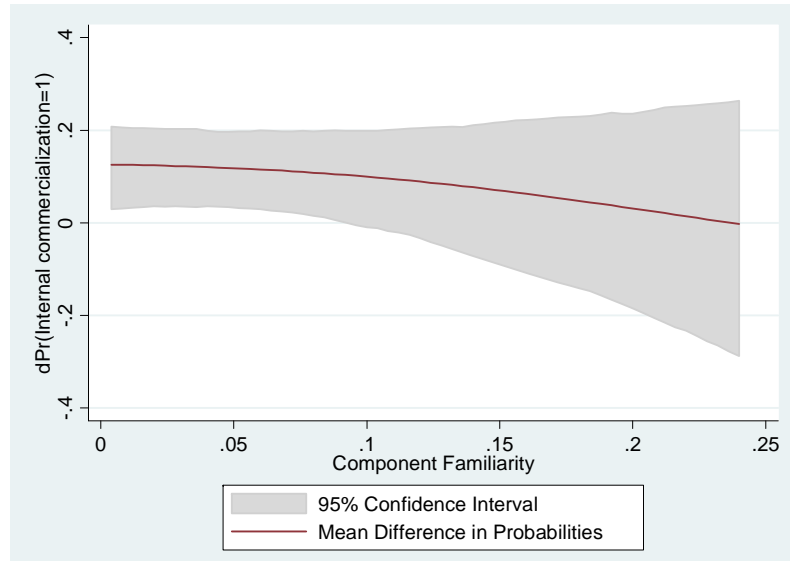

(b) Difference in predicted probabilities of internal commercialization

Figure 2 Interaction effects of component familiarity and horizontal collaboration

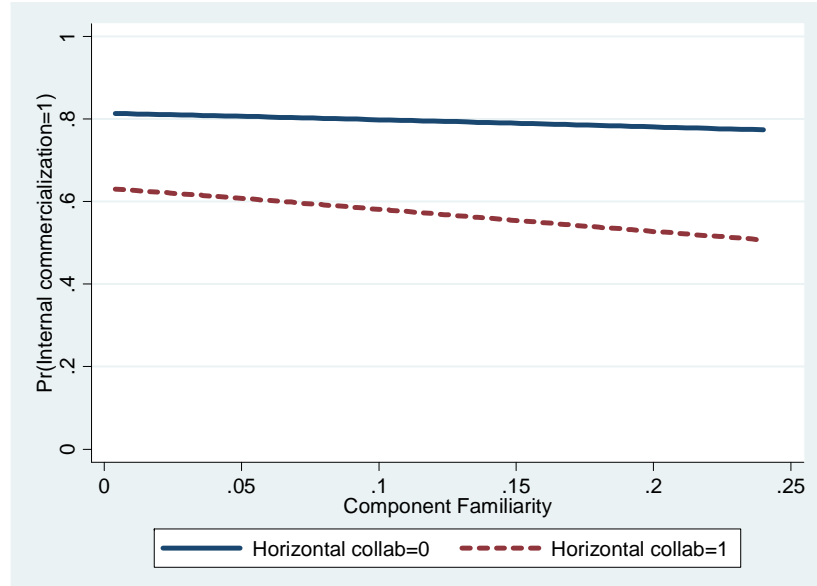

(a) Predicted probability of internal commercialization

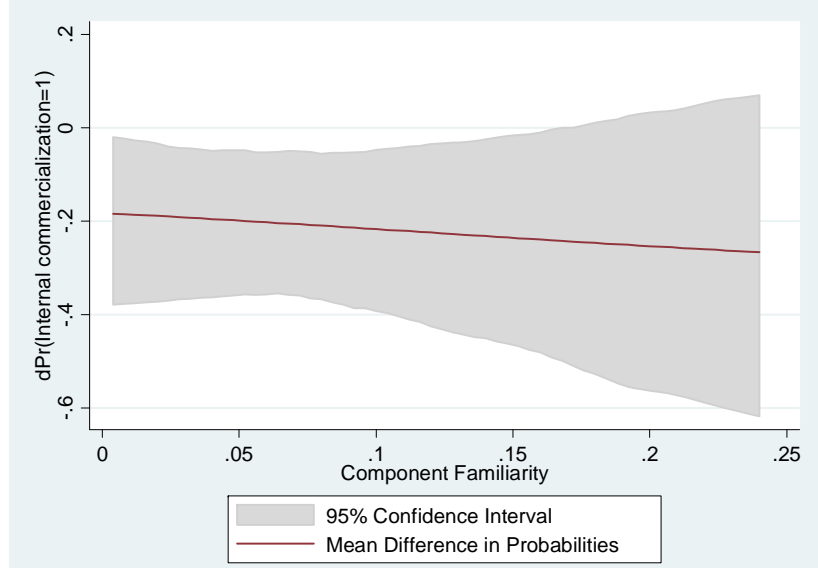

(b) Difference in predicted probabilities of internal commercialization 


\section{CIRCLE ELECTRONIC WORKING PAPERS SERIES (EWP)}

CIRCLE (Centre for Innovation, Research and Competence in the Learning Economy) is a multidisciplinary research centre set off by several faculties at Lund University and Blekinge Institute of Technology. CIRCLE has a mandate to conduct multidisciplinary research and education on the following issues: Long-term perspectives on innovation, structural change and economic growth, Entrepreneurship and venture capital formation with a special focus on new ventures, The dynamics of R\&D systems and technological systems, including their impact on entrepreneurship and growth, Regional innovation systems in different national and international contexts and International comparative analyses of national innovation systems. Special emphasis is done on innovation policies and research policies. 10 nationalities and 14 disciplines are represented among the CIRCLE staff.

The CIRCLE Electronic Working Paper Series are intended to be an instrument for early dissemination of the research undertaken by CIRCLE researchers, associates and visiting scholars and stimulate discussion and critical comment.

The working papers present research results that in whole or in part are suitable for submission to a refereed journal or to the editor of a book or have already been submitted and/or accepted for publication.

CIRCLE EWPs are available on-line at: http://www.circle.lu.se/publications

\section{Available papers:}

\section{1}

WP 2011/01

SMEs' absorptive capacities and large firms' knowledge spillovers: Micro evidence from Mexico

Claudia de Fuentes and Gabriela Dutrénit

WP 2011/02

Comparing knowledge bases: on the organisation and geography of knowledge flows in the regional innovation system of Scania, southern Sweden Roman Martin and Jerker Moodysson

WP 2011/03

Organizational paths of commercializing patented inventions: The effects of transaction costs, firm capabilities, and collaborative ties Taehyun Jung and John P. Walsh 
WP 2010/01

Innovation policies for development: towards a systemic experimentation based approach

Cristina Chaminade, Bengt-Ake Lundvall, Jan Vang-Lauridsen and KJ Joseph

WP 2010/02

From Basic Research to Innovation: Entrepreneurial Intermediaries for Research Commercialization at Swedish 'Strong Research Environments'

Fumi Kitagawa and Caroline Wigren

WP 2010/03 Different competences, different modes in the globalization of innovation?

A comparative study of the Pune and Beijing regions

Monica Plechero and Cristina Chaminade

WP 2010/04 Technological Capability Building in Informal Firms in the Agricultural

Subsistence Sector In Tanzania: Assessing the Role of Gatsby Clubs

Astrid Szogs and Kelefa Mwantima

WP 2010/05

The Swedish Paradox - Unexploited Opportunities!

Charles Edquist

WP 2010/06

A three-stage model of the Academy-Industry linking process: the perspective of both agents

Claudia De Fuentes and Gabriela Dutrénit

WP 2010/07

Innovation in symbolic industries: the geography and organisation of knowledge sourcing

Roman Martin and Jerker Moodysson

WP 2010/08

Towards a spatial perspective on sustainability transitions

Lars Coenen, Paul Benneworth and Bernhard Truffer

WP 2010/09

The Swedish national innovation system and its relevance for the emergence of global innovation networks

Cristina Chaminade, Jon Mikel Zabala and Adele Treccani

WP 2010/10

Who leads Research Productivity Change? Guidelines for R\&D policy makers Fernando Jiménez-Sáez, Jon Mikel Zabala and José L- Zofío

WP 2010/11

Research councils facing new science and technology

Frank van der Most and Barend van der Meulen 
WP 2010/12

From new to the firm to new to the world. Effect of geographical proximity and technological capabilities on the degree of novelty in emerging economies Monica Plechero and Cristina Chaminade

WP 2010/13

Are knowledge-bases enough? A comparative study of the geography of knowledge sources in China (Great Beijing) and India (Pune)

Cristina Chaminade

WP 2010/14

Regional Innovation Policy beyond 'Best Practice': Lessons from Sweden Roman Martin, Jerker Moodysson and Elena Zukauskaite

WP 2010/15

Innovation in cultural industries: The role of university links

Elena Zukauskaite

WP 2010/16

Use and non-use of research evaluation. A literature review

Frank van der Most

WP 2010/17

Upscaling emerging niche technologies in sustainable energy: an international comparison of policy approaches

Lars Coenen, Roald Suurs and Emma van Sandick 
WP 2009/01

Building systems of innovation in less developed countries: The role of intermediate organizations.

Szogs, Astrid; Cummings, Andrew and Chaminade, Cristina

WP 2009/02

The Widening and Deepening of Innovation Policy: What Conditions Provide for Effective Governance?

Borrás, Susana

WP 2009/03

Managerial learning and development in small firms: implications based on observations of managerial work

Gabrielsson, Jonas and Tell, Joakim

WP 2009/04

University professors and research commercialization: An empirical test of the "knowledge corridor" thesis

Gabrielsson, Jonas, Politis, Diamanto and Tell, Joakim

WP 2009/05

On the concept of global innovation networks

Chaminade, Cristina

WP 2009/06

Technological Waves and Economic Growth - Sweden in an International Perspective 1850-2005

Schön, Lennart

WP 2009/07

Public Procurement of Innovation Diffusion: Exploring the Role of Institutions and Institutional Coordination

Rolfstam, Max; Phillips, Wendy and Bakker, Elmer

WP 2009/08

Local niche experimentation in energy transitions: a theoretical and empirical exploration of proximity advantages and disadvantages

Lars Coenen, Rob Raven, Geert Verbong

WP 2009/9

Product Development Decisions: An empirical approach to Krishnan and Ulrich Jon Mikel Zabala, Tina Hannemann

WP 2009/10

Dynamics of a Technological Innovator Network and its impact on technological performance

Ju Liu, Cristina Chaminade

WP 2009/11

The Role of Local Universities in Improving Traditional SMEs Innovative Performances: The Veneto Region Case

Monica Plechero 
WP 2009/12

Comparing systems approaches to innovation and technological change for sustainable and competitive economies: an explorative study into conceptual commonalities, differences and complementarities

Coenen, Lars and Díaz López, Fernando J.

WP 2009/13

Public Procurement for Innovation (PPI) - a Pilot Study

Charles Edquist

WP 2009/14

Outputs of innovation systems: a European perspective

Charles Edquist and Jon Mikel Zabala 
WP 2008/01

R\&D and financial systems: the determinants of R\&D expenditures in the Swedish pharmaceutical industry

Malmberg, Claes

WP 2008/02

The Development of a New Swedish Innovation Policy. A Historical Institutional Approach

Persson, Bo

WP 2008/03

The Effects of R\&D on Regional Invention and Innovation

Olof Ejermo and Urban Gråsjö

WP 2008/04

Clusters in Time and Space: Understanding the Growth and Transformation of Life Science in Scania

Moodysson, Jerker; Nilsson, Magnus; Svensson Henning, Martin

WP 2008/05

Building absorptive capacity in less developed countries

The case of Tanzania

Szogs, Astrid; Chaminade, Cristina and Azatyan, Ruzana

WP 2008/06

Design of Innovation Policy through Diagnostic Analysis:

Identification of Systemic Problems (or Failures)

Edquist, Charles

WP 2008/07

The Swedish Paradox arises in Fast-Growing Sectors

Ejermo, Olof; Kander, Astrid and Svensson Henning, Martin

WP 2008/08

Policy Reforms, New University-Industry Links and Implications for Regional Development in Japan

Kitagawa, Fumi

WP 2008/09

The Challenges of Globalisation: Strategic Choices for Innovation Policy

Borrás, Susana; Chaminade, Cristina and Edquist, Charles

WP 2008/10

Comparing national systems of innovation in Asia and Europe: theory and comparative framework

Edquist, Charles and Hommen, Leif

WP 2008/11

Putting Constructed Regional Advantage into Swedish Practice? The case of the VINNVÄXT initiative 'Food Innovation at Interfaces'

Coenen, Lars; Moodysson, Jerker 
WP 2008/12

Energy transitions in Europe: 1600-2000

Kander, Astrid; Malanima, Paolo and Warde, Paul

WP 2008/13

RIS and Developing Countries: Linking firm technological capabilities to regional systems of innovation

Padilla, Ramon; Vang, Jan and Chaminade, Cristina

WP 2008/14

The paradox of high R\&D input and low innovation output: Sweden

Bitarre, Pierre; Edquist, Charles; Hommen, Leif and Ricke, Annika

WP 2008/15

Two Sides of the Same Coin? Local and Global Knowledge Flows in Medicon Valley

Moodysson, Jerker; Coenen, Lars and Asheim, Bjørn

WP 2008/16

Electrification and energy productivity

Enflo, Kerstin; Kander, Astrid and Schön, Lennart

WP 2008/17

Concluding Chapter: Globalisation and Innovation Policy

Hommen, Leif and Edquist, Charles

WP 2008/18

Regional innovation systems and the global location of innovation activities: Lessons from China

Yun-Chung, Chen; Vang, Jan and Chaminade, Cristina

WP 2008/19

The Role of mediator organisations in the making of innovation systems in least developed countries. Evidence from Tanzania

Szogs, Astrid

WP 2008/20

Globalisation of Knowledge Production and Regional Innovation Policy:

Supporting Specialized Hubs in the Bangalore Software Industry

Chaminade, Cristina and Vang, Jan

WP 2008/21

Upgrading in Asian clusters: Rethinking the importance of interactive-learning Chaminade, Cristina and Vang, Jan 
WP 2007/01

Path-following or Leapfrogging in Catching-up: the Case of Chinese Telecommunication Equipment Industry

Liu, Xielin

WP 2007/02

The effects of institutional change on innovation and productivity growth in the Swedish pharmaceutical industry

Malmberg, Claes

WP 2007/03

Global-local linkages, Spillovers and Cultural Clusters: Theoretical and Empirical insights from an exploratory study of Toronto's Film Cluster

Vang, Jan; Chaminade, Cristina

WP 2007/04

Learning from the Bangalore Experience: The Role of Universities in an Emerging Regional Innovation System

Vang, Jan; Chaminade, Cristina.; Coenen, Lars.

WP 2007/05

Industrial dynamics and innovative pressure on energy -Sweden with European and Global outlooks

Schön, Lennart; Kander, Astrid.

WP 2007/06

In defence of electricity as a general purpose technology

Kander, Astrid; Enflo, Kerstin; Schön, Lennart

WP 2007/07

Swedish business research productivity - improvements against international trends

Ejermo, Olof; Kander, Astrid

WP 2007/08

Regional innovation measured by patent data - does quality matter?

Ejermo, Olof

WP 2007/09

Innovation System Policies in Less Successful Developing countries: The case of Thailand

Intarakumnerd, Patarapong; Chaminade, Cristina 
WP 2006/01

The Swedish Paradox

Ejermo, Olof; Kander, Astrid

WP 2006/02

Building RIS in Developing Countries: Policy Lessons from Bangalore, India Vang, Jan; Chaminade, Cristina

WP 2006/03

Innovation Policy for Asian SMEs: Exploring cluster differences

Chaminade, Cristina; Vang, Jan.

WP 2006/04

Rationales for public intervention from a system of innovation approach: the case of VINNOVA.

Chaminade, Cristina; Edquist, Charles

WP 2006/05

Technology and Trade: an analysis of technology specialization and export flows

Andersson, Martin; Ejermo, Olof

WP 2006/06

A Knowledge-based Categorization of Research-based Spin-off Creation

Gabrielsson, Jonas; Landström, Hans; Brunsnes, E. Thomas

WP 2006/07

Board control and corporate innovation: an empirical study of small technology-based firms

Gabrielsson, Jonas; Politis, Diamanto

WP 2006/08

On and Off the Beaten Path:

Transferring Knowledge through Formal and Informal Networks

Rick Aalbers; Otto Koppius; Wilfred Dolfsma

WP 2006/09

Trends in R\&D, innovation and productivity in Sweden 1985-2002

Ejermo, Olof; Kander, Astrid

WP 2006/10

Development Blocks and the Second Industrial Revolution, Sweden 1900-1974

Enflo, Kerstin; Kander, Astrid; Schön, Lennart

WP 2006/11

The uneven and selective nature of cluster knowledge networks: evidence from the wine industry

Giuliani, Elisa

WP 2006/12

Informal investors and value added: The contribution of investors' experientially acquired resources in the entrepreneurial process 
Politis, Diamanto; Gabrielsson, Jonas

WP 2006/13

Informal investors and value added: What do we know and where do we go?

Politis, Diamanto; Gabrielsson, Jonas

WP 2006/14

Inventive and innovative activity over time and geographical space: the case of Sweden

Ejermo, Olof 
WP 2005/1

Constructing Regional Advantage at the Northern Edge

Coenen, Lars; Asheim, Bjørn

WP 2005/02

From Theory to Practice: The Use of the Systems of Innovation Approach for Innovation Policy

Chaminade, Cristina; Edquist, Charles

WP 2005/03

The Role of Regional Innovation Systems in a Globalising Economy: Comparing Knowledge Bases and Institutional Frameworks in Nordic Clusters Asheim, Bjørn; Coenen, Lars

WP 2005/04

How does Accessibility to Knowledge Sources Affect the Innovativeness of Corporations? Evidence from Sweden

Andersson, Martin; Ejermo, Olof

WP 2005/05

Contextualizing Regional Innovation Systems in a Globalizing Learning Economy: On Knowledge Bases and Institutional Frameworks

Asheim, Bjørn; Coenen, Lars

WP 2005/06

Innovation Policies for Asian SMEs: An Innovation Systems Perspective Chaminade, Cristina; Vang, Jan

WP 2005/07

Re-norming the Science-Society Relation

Jacob, Merle

WP 2005/08

Corporate innovation and competitive environment

Huse, Morten; Neubaum, Donald O.; Gabrielsson, Jonas

WP 2005/09

Knowledge and accountability: Outside directors' contribution in the corporate value chain

Huse, Morten, Gabrielsson, Jonas; Minichilli, Alessandro

WP 2005/10

Rethinking the Spatial Organization of Creative Industries

Vang, Jan

WP 2005/11

Interregional Inventor Networks as Studied by Patent Co-inventorships

Ejermo, Olof; Karlsson, Charlie

WP 2005/12

Knowledge Bases and Spatial Patterns of Collaboration: Comparing the Pharma and Agro-Food Bioregions Scania and Saskatoon 
Coenen, Lars; Moodysson, Jerker; Ryan, Camille; Asheim, Bjørn; Phillips, Peter

WP 2005/13

Regional Innovation System Policy: a Knowledge-based Approach

Asheim, Bjørn; Coenen, Lars; Moodysson, Jerker; Vang, Jan

WP 2005/14

Face-to-Face, Buzz and Knowledge Bases: Socio-spatial implications for learning and innovation policy

Asheim, Bjørn; Coenen, Lars, Vang, Jan

WP 2005/15

The Creative Class and Regional Growth: Towards a Knowledge Based Approach

Kalsø Hansen, Høgni; Vang, Jan; Bjørn T. Asheim

WP 2005/16

Emergence and Growth of Mjärdevi Science Park in Linköping, Sweden

Hommen, Leif; Doloreux, David; Larsson, Emma

WP 2005/17

Trademark Statistics as Innovation Indicators? - A Micro Study

Malmberg, Claes 